\title{
A Review of Crop Husbandry and Soil Management Practices Using Meta-Analysis Studies: Towards Soil-Improving Cropping Systems
}

\author{
René Rietra *(D), Marius Heinen (D) and Oene Oenema (D)
}

check for

updates

Citation: Rietra, R.; Heinen, M.; Oenema, O. A Review of Crop Husbandry and Soil Management Practices Using Meta-Analysis Studies: Towards Soil-Improving Cropping Systems. Land 2022, 11, 255. https://doi.org/10.3390/land 11020255

Academic Editors: Guido Wyseure, Julián Cuevas González and Jean Poesen

Received: 13 January 2022

Accepted: 30 January 2022

Published: 8 February 2022

Publisher's Note: MDPI stays neutral with regard to jurisdictional claims in published maps and institutional affiliations.

Copyright: (C) 2022 by the authors. Licensee MDPI, Basel, Switzerland. This article is an open access article distributed under the terms and conditions of the Creative Commons Attribution (CC BY) license (https:// creativecommons.org/licenses/by/ $4.0 /$ )
Wageningen Environmental Research, Wageningen University \& Research, Droevendaalsesteeg 3, 6708 PB Wageningen, The Netherlands; marius.heinen@wur.nl (M.H.); oene.oenema@wur.nl (O.O.) * Correspondence: rene.rietra@wur.nl

\begin{abstract}
Coherent improvements in crop varieties and crop husbandry and soil management practices are needed to increase global crop production in a sustainable manner. However, these practices are often discussed separately, and as a result there is little overview. Here, we present a database and synthesis of 154 meta-analysis studies related to ten main crop husbandry and soil management practices, including crop type and rotations, tillage, drainage, nutrient management, irrigation and fertigation, weed management, pest management, crop residue management, mechanization and technology, and landscape management. Most meta-analysis studies were related to tillage (55), followed by crop type and rotations (32), nutrient management (25), crop residue management (19), and irrigation and fertigation (18). Few studies were related to landscape management (6) and mechanization and technology (2). In terms of outcome, studies focused on crop yield and quality (81), soil quality (73), and environmental impacts (56), and little on economic effects (7) or resource use efficiency (24). Reported effects of alternative practices, relative to conventional practice, were positive in general. Effect sizes were relatively large for environmental effects (nutrient leaching, greenhouse gas emissions), and small for soil quality (except for soil life) and crop yield. Together, meta-analysis studies indicate that there is large scope for increasing cropland productivity and minimizing environmental impacts. A roadmap is provided for integration and optimization of all ten practices, and recommendations are formulated to address the gaps in meta-analysis studies.
\end{abstract}

Keywords: crop residue; crop rotation; crop yield; environmental effects; irrigation; nutrient management; resource use; soil-improving cropping systems; soil quality; tillage

\section{Introduction}

Global yields of main crops (wheat, rice, maize, and soybean) have increased by an average 1 to $2 \%$ per year during the last decades [1,2], in response to the increasing global food and feed demands, and facilitated through technological improvements. Forecasts suggest that mean crop yields per ha of cropland have to increase by as much as $2.4 \%$ per year to be able to meet the food and feed demands by the human population in 2050, also because further expansion of global cropland area and/or increased frequency of harvesting are not feasible [3,4]. The slow-moving mean increase in global crop yields during recent decades are in part related to areas where crop yields have been stagnating and to areas where crop yields have not increased at all or have fallen. Recent analyses suggest that crop yields are not increasing on 25 to $40 \%$ of the harvested global cropland area [1]. Yield increases of wheat, maize, and rice tend to be lowest in low-income countries because of lack of resources and poor crop husbandry practices. In high-income countries, yield increases may be less than average when actual yields approach attainable crop yields, suggesting that yields reach biophysical limits [5,6]. Crop yields may also stagnate in some countries because of climate change and environmental regulations [7-9] and soil degradation [10-12]. 
The yield increases per unit of surface area during recent decades have mainly been the result of improved germplasm and improved crop husbandry and soil management practices, including inputs of fertilizers, irrigation, and pesticides [13]. Availability of highyielding cultivars, fertilizers, irrigation water, and pesticides are commonly considered to be the dominant yield-controlling factors, next to climate and soil quality. However, the importance of precise timing and careful execution of the various crop husbandry practices in the proper order should not be neglected [13]. The crop husbandry and soil management practices together determine how far actual crop yields deviate from attainable crop yields and from potential crop yields [14]. Attainable crop yields, defined as the best yield achieved by the best farms through skillful use of the best available technology [14], are on average 70 to $80 \%$ of the potential yield. Potential crop yields are commonly defined as the yields obtained when cultivars adapted to the local environmental conditions are grown with minimal stress, achieved with best management practices $[11,15,16]$. Actual yields on farmers' fields range from 30 to 100\% of attainable yields, depending on region [1].

Crop husbandry and soil management practices also influence the environmental sustainability of crop production systems, especially in cases where the pressures to increase crop yields are high. Concerns have arisen about intensive crop production systems with poor crop husbandry and soil management practices, as these pollute groundwater and surface waters with nitrogen $(\mathrm{N})$, phosphorus $(\mathrm{P})$ and pesticides, and emit greenhouse gases and ammonia $\left(\mathrm{NH}_{3}\right)$ into the atmosphere [15-17]. There are also concerns about soil degradation through processes such as erosion, salinization, compaction, and declines of soil organic matter content and soil biodiversity [10]. The United Nations (UN) Sustainable Development Goals (SDGs) address essentially all of these concerns and indirectly guide the actions of nations in the pursuit of a more sustainable world. Of the 17 SDGs, at least five have a direct relation with cropping systems and soils, while others have a more indirect relation [18]. SDG-2 aims to 'end hunger, achieve food and nutrition security, and promote sustainable agriculture' and is key to the success of the SDG agenda [19].

While there are several spatially explicit assessments of changes in crop yields over time (e.g., [2,20], there are no spatially explicit, integrated assessments of the sustainability of crop husbandry and soil management practices. The main reason for this lack of assessments is the diversity of crop husbandry and soil management practices, and the lack of methods and procedures for making such integrated assessments. Wezel et al. [21] analyzed 15 agroecological cropping practices qualitatively in terms of possible advantages and drawbacks, for temperate areas. Others have reviewed the impacts of one or a few specific crop husbandry practices (e.g., [22-24], often on the basis of a meta-analysis of published studies. There is as yet no coherent overview and comparison of the effects of all main crop husbandry and soil management practices.

The aim of this study was to provide a review of crop husbandry and soil management practices on the basis of meta-analysis studies. Meta-analysis papers commonly analyze and synthesize many experimental studies related to topical research questions and/or ambiguous research findings. The term 'meta-analysis' was first used in 1976 and referred to 'the statistical analysis of a large collection of analysis results from individual studies for the purpose of integrating the findings' $[25,26]$. Most meta-analysis studies related to crop husbandry and soil management practices date from the last 10 to 20 years, and the cumulative number has increased exponentially (Figure 1).

Thus, our main hypothesis is that meta-analysis studies summarize and synthesize vast amounts of research results, and unravel underlying mechanisms of variations, and thereby provide overview. By reviewing and synthesizing meta-analysis studies related to several crop husbandry and soil management practices, we aimed to (i) summarize the main impacts of these crop husbandry and soil management practices, (ii) identify the most topical research areas, and (iii) suggest guidelines for 'sustainable cropping systems'. The crop husbandry and soil management practices examined were assessed in terms of (a) crop yield and quality, (b) soil quality, (c) economic effects, (d) resource use efficiency, 
(e) environmental effects, and (f) human health impacts. However, none of the reviewed studies addressed human health impacts; as a consequence, this aspect is not reported here.

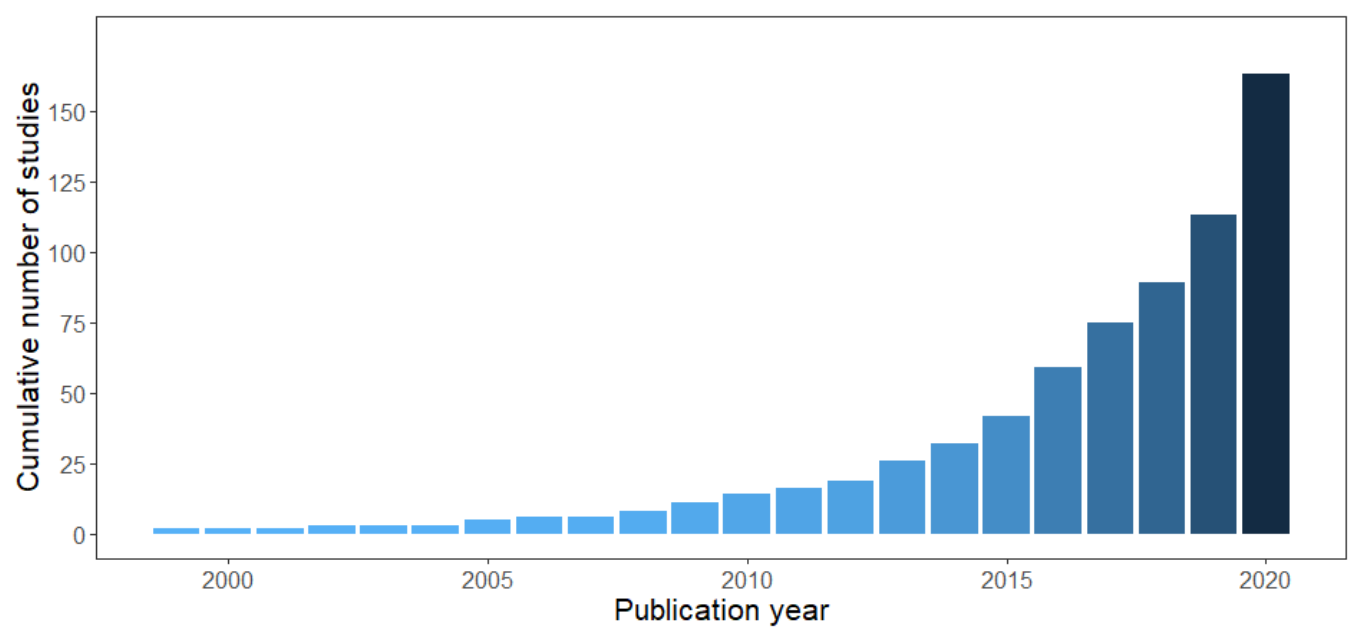

Figure 1. Exponential increase in time of published studies used in our overview (the bar left of 2000 refers to all studies before the year 2000). In total 163 unique studies (peer-reviewed publications) were used: 154 meta-analysis studies and 9 reviews.

\section{Materials and Methods}

\subsection{Data Collection}

We reviewed meta-analyses studies related to crop husbandry and soil management practices (henceforth 'practices'). A total of ten main categories of practices were examined: (1) crop type and crop rotations including intercropping, cover crops, (2) nutrient management, (3) irrigation and fertigation, (4) controlled drainage, (5) tillage practices, (6) pest management, (7) weed management, (8) crop residue management including mulching, (9) mechanization including precision technology, and (10) landscape management, including hedgerows, tree lines, buffer strips. These ten categories of practices relate to the main crop yield defining, limiting, and reducing factors [11,15,16], and with climate-related factors (not included here) have very dominant effects on crop yield and quality, soil quality, and the environmental impacts of crop production.

For each of these categories, quantitative effects of specific practices were distilled from the meta-analysis studies. In most studies, an improved or modified practice was compared with the conventional practice. We focused on the following five outcomes (impacts): (a) crop yield and quality, (b) soil quality, (c) farm income, (d) resource use efficiency, and (e) environmental effects. We attributed the indicators that were used in the meta-analysis to these five outcomes. For crop yield and quality, farm income, and resource use efficiency, a limited number of straightforward indicators were used commonly, but for soil quality and environmental effects a wide range of indicators have been reported. We made no selection in these indicators. We focused on effect sizes defined as the standardized mean difference between the effect of a specific treatment practice relative to that of the control treatment. It is often given as the response ratio (RR) which is the ratio of the effect of a specific treatment $(X t)$ and the control treatment $(X \mathrm{c})$, with or without natural $\log$ of the ratio.

We collected data from peer-reviewed meta-analysis publications only. The publications were identified using the online database Scopus (https:/ / www.scopus.com/sources, accessed on 5 May 2021) within the period 1997-2020. Publications were searched using the keywords "meta-analysis" and the results were refined using additional words-"crop type", "crop rotation", "nutrient management", "fertilization", "irrigation", "fertigation", "drainage", "tillage", " pest management", "disease management", "weed management", "crop residue management", "mulching", "mechanization", "landscape management", "hedgerows", and "buffer strips". These keywords were searched for in the title, abstract, 
and keywords. Additionally, we used the forward and backward snowballing technique when applicable and a few review studies that presented quantitative data, such as a meta-analysis, were included as well. Further information about the selection and analysis of data is provided in the Supplementary Materials.

A list of abbreviations used in this publication is given in Table A1 (Appendix A).

\subsection{Data Compilation and Analysis}

Data from the meta-analysis studies were compiled in Windows Excel. The region of the study, the specific practice, the conventional (control) practice, the results, the units and the number of observations were recorded. No further data processing and analyses of the data were undertaken. The Windows Excel database, with all results extracted from the meta-analyses studies, is in the Supplementary Materials.

\section{Results}

\subsection{Overview}

Table 1 presents an overview of the meta-analysis studies across categories of practices. Most of the meta-analysis studies dealt with tillage practices (55). Crop type and crop rotations (32), nutrient management (25), irrigation and fertigation (18), and crop residue management (19) have also been analyzed frequently. In contrast, only two studies related to mechanization and (precision) technology.

Table 1. Summary of the number of reviewed meta-analysis studies across crop husbandry and soil management practices, and across aspects (outcome). Note that the sum of the studies for the different aspects can be larger than the number of meta-analysis studies since some studies reported on several aspects.

\begin{tabular}{|c|c|c|c|c|c|c|}
\hline \multirow[b]{2}{*}{$\begin{array}{l}\text { Crop Husbandry and Soil } \\
\text { Management Practices }\end{array}$} & \multicolumn{6}{|c|}{ Number of Meta-Analysis Studies per Aspect } \\
\hline & Total & $\begin{array}{l}\text { Crop Yield \& } \\
\text { Quality }\end{array}$ & $\begin{array}{c}\text { Soil } \\
\text { Quality }\end{array}$ & $\begin{array}{l}\text { Resource Use } \\
\text { Efficiency }\end{array}$ & $\begin{array}{l}\text { Economic } \\
\text { Aspects }\end{array}$ & $\begin{array}{l}\text { Environmental } \\
\text { Impacts }\end{array}$ \\
\hline 1 Crop type and crop rotations & 32 & 12 & 12 & 2 & 1 & 14 \\
\hline 2 Nutrient management $\#$ & 25 & 12 & 9 & 0 & 1 & 7 \\
\hline 3 Irrigation and fertigation & 18 & 12 & 2 & 11 & 0 & 4 \\
\hline 4 Drainage & 6 & 1 & 1 & 0 & 1 & 4 \\
\hline 5 Tillage & 55 & 19 & 36 & 5 & 2 & 14 \\
\hline 6 Pest management & 7 & 3 & 3 & 0 & 0 & 1 \\
\hline 7 Weed management & 4 & 2 & 2 & 0 & 0 & 0 \\
\hline 8 Crop residue and mulching & 19 & 14 & 5 & 6 & 1 & 8 \\
\hline 9 Mechanization and technology & 2 & 3 & 1 & 0 & 1 & 0 \\
\hline 10 Landscape management & 6 & 3 & 2 & 0 & 0 & 4 \\
\hline Total & $174 \&$ & 81 & 73 & 24 & 7 & 56 \\
\hline
\end{tabular}

\#: one reference included the human health related aspect survival time of zoonotic pathogens; \&: The total number of studies reported here consisted of 163 unique publications, some of which considered more than one crop husbandry or soil management practice.

Most meta-analysis studies examined the effects of specific practices on crop yield and quality (81). For soil quality (73 studies), soil organic matter content was the main focus. For environmental effects (56 studies), the focus was mainly on greenhouse gas emissions and nitrate leaching. Resource use efficiency was examined mainly for irrigation and fertigation, nutrient management and tillage. Only seven meta-analysis studies included economic aspects (Table 1).

The meta-analysis studies reviewed covered a large number of experimental studies and practices in different parts of the world. Each meta-analysis study was based on a large number of underlying studies (on average more than 100; range 8 to 678). In order to attain an impression of how often literature sources have been used in multiple metaanalysis studies, we collected and examined the literature sources of the 55 meta analyses on tillage. In most cases, references to the original studies were provided in the supporting 
information, but for seven out of the 55 meta-analyses studies no references were made available. For the remaining 48 studies we collected in total 5465 references to original studies. These were then manually checked on replicate use. Over two-third of these references were used only once, $26 \%$ of these were used in two meta-analysis studies, $4 \%$ were used three times, and $2 \%$ were used four times. Three references were used in seven meta-analyses studies. We conclude that essentially all meta-analyses related to tillage were based on unique studies, which replicated use of original studies is relatively small (given the large number of meta-analyses related to tillage), and that the results of these meta-analyses are largely independent on each other therefore. We did not check repeated use of original studies for other categories of practices.

\subsection{Crop Type and Crop Rotation}

Selecting the proper crop varieties and crop rotations is often farm and region-specific and key to successful crop farming. Crop rotation is the practice of planting different crops sequentially on the same field, mainly to combat pest and weed pressures and improve soil quality, and thereby to enhance crop yield sustainably. Crop rotations have been the subject of many meta-analysis (Table 1), whereby almost equal attention has been given to crop yield, soil quality, and environmental effects, but little attention to the economic aspects and to resource use efficiency. Specific crop varieties and cultivars have not been the subject of meta-analysis.

Effects of crop rotation, intercropping, and cover crops on crop yield, soil quality, and the environment were positive in almost all studies (Figure 2). Pre-crops before wheat [27] and especially legumes as pre-crops [28] had positive effects on wheat yield, soil quality, and pesticide use [29]. However, effects of pre-crops depend on the nitrogen fertilization rate: yield benefits are highest under low nitrogen fertilization [28]. Indeed, interactions with other crop husbandry and soil management hold for many crop rotation effects; nutrient management, irrigation, pest, disease, and weed management all have a large impact on the effect size of crop rotations [30-32].

The simultaneous cultivation of two or more crop species within one field for at least a part of the growing period (intercropping) also has positive effects on crop yield, but the effect size strongly depends on the crop types and intercropping patterns [30,33]. Growing cover or catch crops after the main crop reduces soil erosion and nitrate leaching and contributes to soil carbon sequestration [34,35], but requires labor and the suppressive effects on pest, diseases and weeds are not always positive. Growing mixtures of varieties of cereals [36] or mixtures of grasses [37] has positive effects on yield (stability) and nitrogen use efficiency.

Effects of crop rotations on GHG emission are variable [38]; this holds also for the effects on cover crops on GHG emissions [39].

\subsection{Nutrient Management}

The 25 meta-analysis studies related to nutrient management have paid more or less equal attention to crop yield and quality, soil quality, and environmental effects, but little or no attention to economic effects and resource use efficiency (Table 1). Almost all studies reported significant positive effect sizes of the studied nutrient management practices relative to conventional practices (Figure 3).

A main focus has been the characterization of differences between fertilizer types, especially between organic and mineral fertilizers $[65,66,78,80]$ and between 'conventional' fertilizers and fertilizers with inhibitors [71,74], in relation to fertilizer effectiveness, soil quality, and environmental impacts. Deriving the optimal nutrient application rates have been the topic of many experimental studies in the past, and this has also been the subject of several meta-analysis studies $[64,68,70]$. Better timing of fertilization and placement of fertilizers gave positive effects on yields in most cases [75,84]. Soil liming increased crop yields, especially when $\mathrm{pH}$ was low [67]. Positive effects of organic soil amendments and mineral fertilizers on soil biological activity and microbial biomass were found, while 
the response of soil enzyme activity depended on enzyme type [68,70,80,81]. Nitrous oxide emissions from cropland increase with nitrogen fertilization, but the increase can be mitigated through better compliance with fertilizer recommendations, and the use of nitrification inhibitors and biochar [72]. Slurry acidification, deep placement, and urease inhibitors decreases ammonia emissions from slurries and urea fertilizers applied to soil $[76,86]$. No meta-analysis studies related to the effectiveness of manure products from different manure processing techniques [87]. Increasing grazing intensity of pastures increased C, N, and P losses from these pastures ([83] as well as the transfer of zoonotic pathogens to water courses [77]). Only few studies pointed at the effects of interactions between categories of practices, including interactions between intercropping, tillage, and fertilizers types in fruit yield [63], interactions between fertilization, and irrigation in fruit yields $[70,88]$ and in maize yields [70].

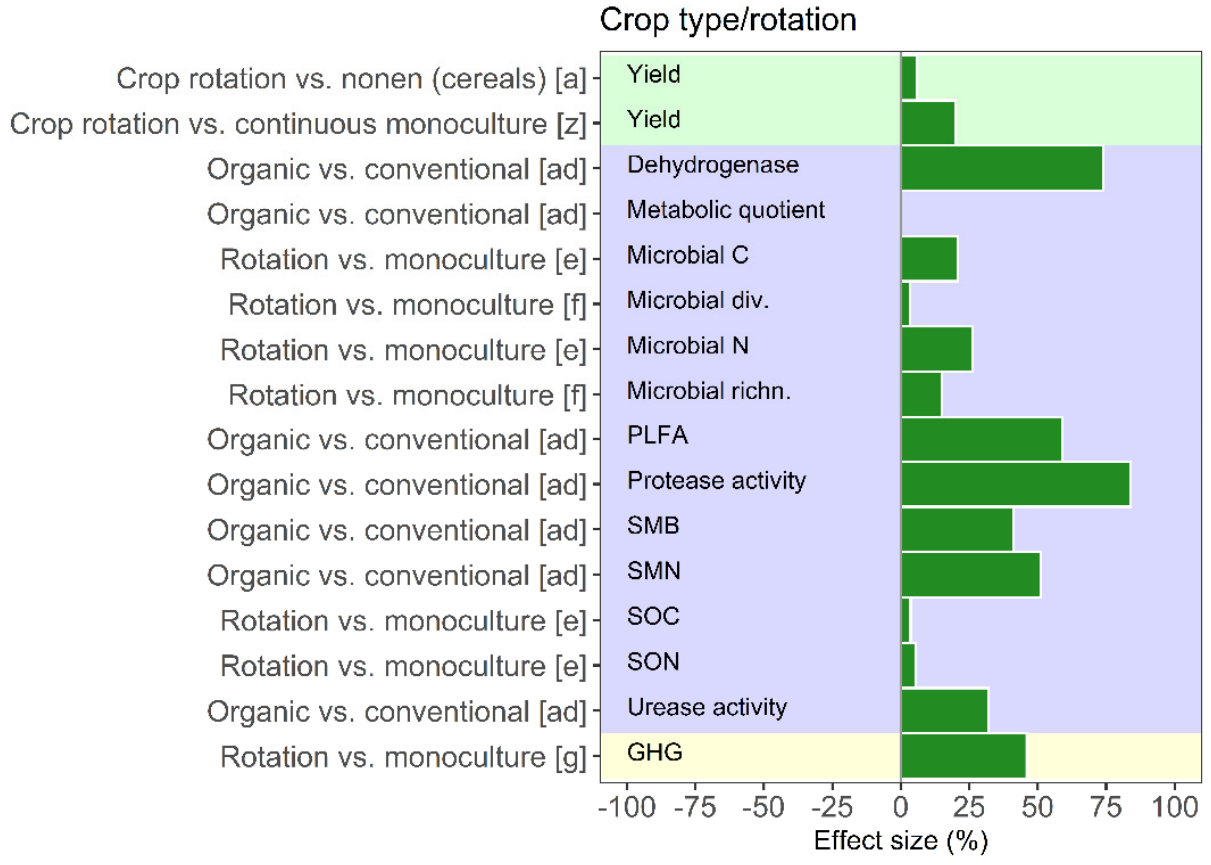

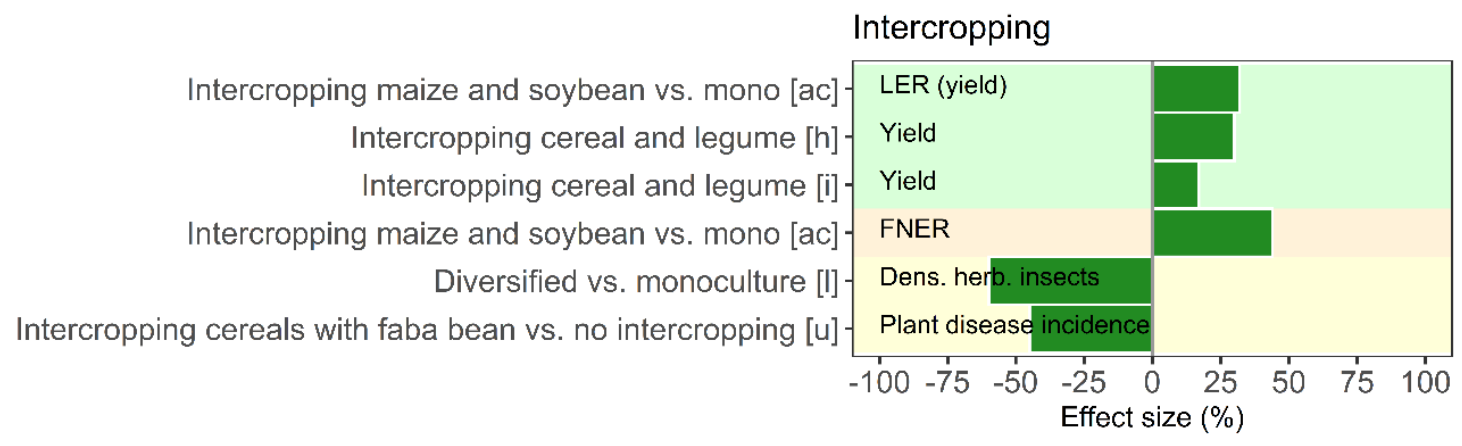

Figure 2. Cont. 


\section{Cover crops}

Grass cover crop vs. fallow before maize (N Am.) [m] Yield

Legume vs. fallow before maize (N Am.) [m] - Yield

Biculture winter cover crop vs. fallow before maize (N Am.) [m]- Yield

Non-legume cover crop vs. fallow in winter $[\mathrm{p}]$ - Yield

Leguminous cover crop vs. fallow in winter $[p]$ - Yield

Cover crops vs. none [aa] - Yield

Cover crops vs, none [aa]- Aggregate stability

Cover crops versus fallow [o]- AMF

Winter cover crops in Mediterranean vs. no winter cover [ab]

Cover crops vs. none [aa]

Cover crops vs. none [aa]

Cover crops vs. none [aa]

Cover crops vs. none [af]

Cover crops vs. none [aa]

Cover crops vs. none [aa]

Cover crops vs. none [aa]

Cover crops vs. none [aa]

Cover crops vs. none [aa]

Winter cover crops in Mediterranean vs. no winter cover [ab]

Cover crops vs. none [aa]

Winter cover crops in Mediterranean vs. no winter cover [ab]

Cover crops vs. none [aa]

Cover crops vs. none [ae]

Winter cover crops in Mediterranean vs. no winter cover [ab] Winter cover crops in Mediterranean vs. no winter cover [ab] Winter cover crops in Mediterranean vs. no winter cover [ab]

Cover crops vs. none in corn-soybean rotation in U.S. Midwest [y]

Winter cover crops in Mediterranean vs. no winter cover [ab]

Cover crops vs. none [aa]

Cover crops vs. fallow: whole-year $[\mathrm{x}]$

Cover crops vs. fallow: only cover crops period $[\mathrm{x}]$

Cover crops vs. fallow [v]

Non-legume cover crop vs. bare: in Nordic countries [p]

Non-legume cover crop vs. bare: global [q]

Non-legume cover crop vs. bare: global [w]

Non-legume cover crop vs. bare: irrigated systems [r]

Cover crops vs. fallow [v]

Cover crops vs. fallow [v]

\section{Crop damage}

Dry bulk density

Erosion

Infiltration

Infiltration

Ksat

Leaching

MBN

MBN

$\mathrm{N}$ tot.

$\mathrm{N}$ tot.

Runoff

SMB

SOC

SOC

SOM

Water content

Weed abundance

Weed biomass

Weed diversity

Weed suppression

$\mathrm{N} 2 \mathrm{O}$

$\mathrm{N} 2 \mathrm{O}$

Nematode abund.

$\mathrm{NO} 3$

$\mathrm{NO} 3$

$\mathrm{NO} 3$

$\mathrm{NO} 3$

ratio $\mathrm{GHG}: \mathrm{CO} 2$

ratio GHG: N2O

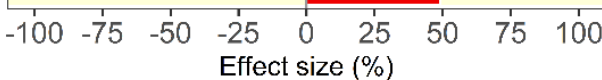

Figure 2. Overall effect sizes (response ratios) reported in meta-analysis studies on cropping (split in crop types and crop rotation, cover crops, intercropping, and perennial crops) grouped per area of interest (light green: agronomic; light blue: soil quality; light orange: resource use efficiency; light brown: economic (no data); light yellow: environmental impacts). The management or treatment comparison is indicated outside the y-axis and the variable to which the data refer are listed inside the $\mathrm{y}$-axis (abbreviations can be found in Table A1). Green bars indicate improvement, red bars indicate worsening. See also Table S1. [a]: [24]; [b]: [28]; [c]: [27]; [d]: [40]; [e]: [41]; [f]: [42]; [g]: [38]; [h]: [43]; [i]: [44]; [j]: [30]; [k]: [45]; [1]: [46]; [m]: [47]; [n]: [48]; [o]: [49]; [p]: [32]; [q]: [31]; [r]: [50]; [s]: [51]; [t]: [52]; [u]: [33]; [v]: [53]; [w]: [54]; [x]: [39]; [y]: [55]; [z]: [56]; [aa]: [57]; [ab]: [58]; [ac]: [59]; [ad]: [60]; [ae]: [61]; [af]: [62]. 


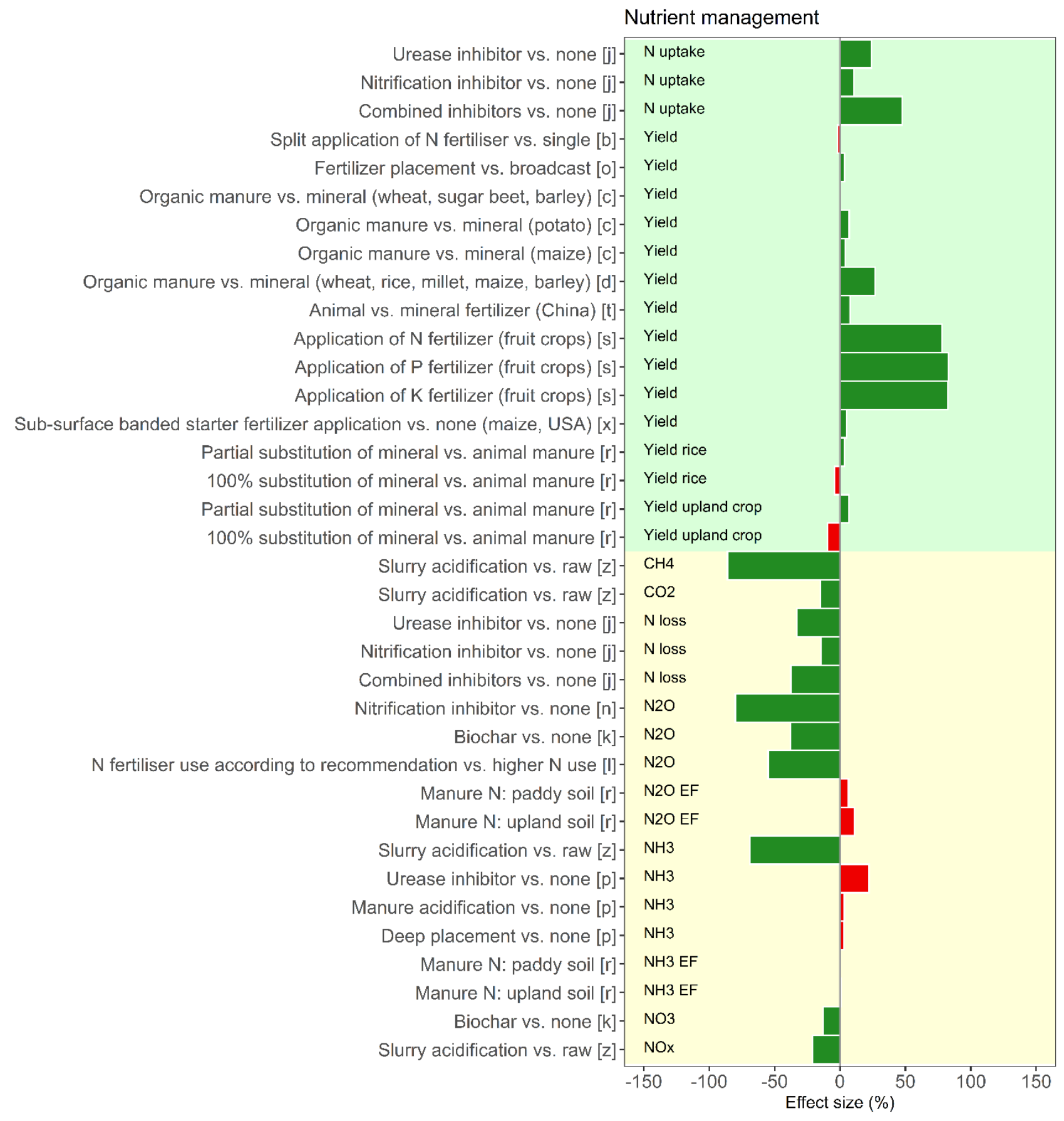

Figure 3. Cont. 
Nutrient management

Animal manure vs. none $[\mathrm{y}]$
Animal vs. mineral fertilizer (China) $[\mathrm{t}]$

$\mathrm{N}$ enrichment in farmland [u]

Animal manure vs. none [y]

$\mathrm{N}$ enrichment in farmland $[\mathrm{u}]$ Organic manure vs. none [m]

Organic manure vs. none [m]

Animal manure vs. none [y]

Animal vs. mineral fertilizer (China) [t]

$\mathrm{N}$ enrichment in farmland [u]

$\mathrm{N}$ enrichment in farmland [u]

$\mathrm{N}$ enrichment in farmland [u]

Animal vs. mineral fertilizer (China) [t]

$\mathrm{N}$ enrichment in farmland [u]

Animal manure vs. none [y]

Animal vs. mineral fertilizer (China) [t]

Organic manure vs. mineral [d]

Animal vs. mineral fertilizer (China) [t]

Animal vs. mineral fertilizer (China) [t]

$\mathrm{N}$ enrichment in farmland $[\mathrm{u}]$

Animal manure vs. none [y]

Animal manure vs. none [y]

Animal vs. mineral fertilizer (China) [t]

Animal vs. mineral fertilizer (China) [t]

$\mathrm{N}$ enrichment in farmland $[\mathrm{U}]$

Animal manure vs. none [y]

$\mathrm{N}$ enrichment in farmland $[\mathrm{u}]$

Animal vs. mineral fertilizer (China) [t]

$\mathrm{N}$ enrichment in farmland [u]

Animal vs. mineral fertilizer (China) [t]

$\mathrm{N}$ enrichment in farmland [u]

Mineral fertiliser vs. none [g]

Inorganic and organic $\mathrm{N}$ fertiliser vs. none [h] Organic manure vs. mineral [d]

Animal vs. mineral fertilizer (China) $[\mathrm{t}]$

$\mathrm{N}$ enrichment in farmland [u]

High grazing intensity vs. low [w]

Effect fertiliser:soil $\mathrm{pH}<6$, soil $\mathrm{pH}>6[\mathrm{v}]$

High grazing intensity vs. low [w]

High grazing intensity vs. low [w]

Mineral fertiliser vs. none [g]

lorganic and organic $\mathrm{N}$ fertiliser vs. none [h]

Organic manure vs. mineral [d]

Animal vs. mineral fertilizer (China) [t]

Animal manure vs. none $[\mathrm{y}]$

Animal vs. mineral fertilizer (China) $[\mathrm{t}]$

Animal vs. mineral fertilizer (China) [t]

Animal manure vs. none [y]

$\mathrm{N}$ enrichment in farmland [u]
Acid phosphalase

Actinomycetes

AG activity

Alkaline phosphatase

AP activity

AWC

AWC

b-1,4-glucosidase

Bacteria

BG activity

BX aclivily

C-acq activity

Catalase

CBII activity

Dehydrogenase

Dry bulk derssily

EEA

Fungi

$\mathrm{K}$ avail.

$\mathrm{MBC}$

MBC

MBN

$\mathrm{N}$ avail

$\mathrm{N}$ tot.

$\mathrm{N}$ tot.

$\mathrm{N}$-acelyl-b-glucosaminidase

OX activity

$P$ avail.

PEO activity

$\mathrm{pH}$

$\mathrm{PHO}$ activity

SMC

SMC

SMC

$\mathrm{SOC}$

SOC

Soil C

Soil fungal diversity

Soil N

Soil $P$

SOM

SOM

SOM

Sucrase

Sulfatase

SWA

urease

Urease

Urease activity

$150-100$

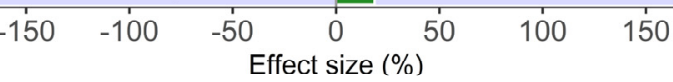

Figure 3. Overall response ratios reported in meta-analysis studies on nutrient management grouped per area of interest (light green: agronomic; light blue: soil quality; light orange: resource use efficiency (no data); light brown: economic (no data); light yellow: environmental impacts). The management or treatment comparison is indicated outside the $y$-axis and the variable to which the data refer are listed inside the y-axis (abbreviations can be found in Table A1). Green bars indicate improvement, red bars indicate worsening. See also Table S2. [a]: [63]; [b]: [64]; [c]: [65]; [d]: [66]; [e]: [67]; [f]: [68]; [g]: [69]; [i]: [70]; [j]: [71]; [k]: [72]; [1]: [39]; [m]: [73]; [n]: [74]; [o]: [75]; [p]: [76]; [q]: [77]; [r]: [78]; [s]: [79]; [t]: [80]; [u]: [81]; [v]: [82]; [w]: [83]; [x]: [84]; [y]: [85]; [z]: [86].

\subsection{Irrigation and Fertigation}

A total of 18 meta-analysis studies related to irrigation and/or fertigation, mainly examining the effects of irrigation methods and amounts on crop yield and water use efficiency for different cropping systems and regions (Table 1). The relative strong focus 
on water use efficiency reflects that irrigation water is a scarce resource. Most studies reported positive effect sizes of irrigation practices on crop yield and water use efficiency relative to conventional irrigation practices (Figure 4). Effect sizes of water productivity of optimal irrigation and deficit irrigation ranged from 20 to $80 \%$. However, some studies also reported negative effects of deficit irrigation practices relative to conventional irrigation practices, possibly because irrigation was reduced too much in deficit irrigation treatments.

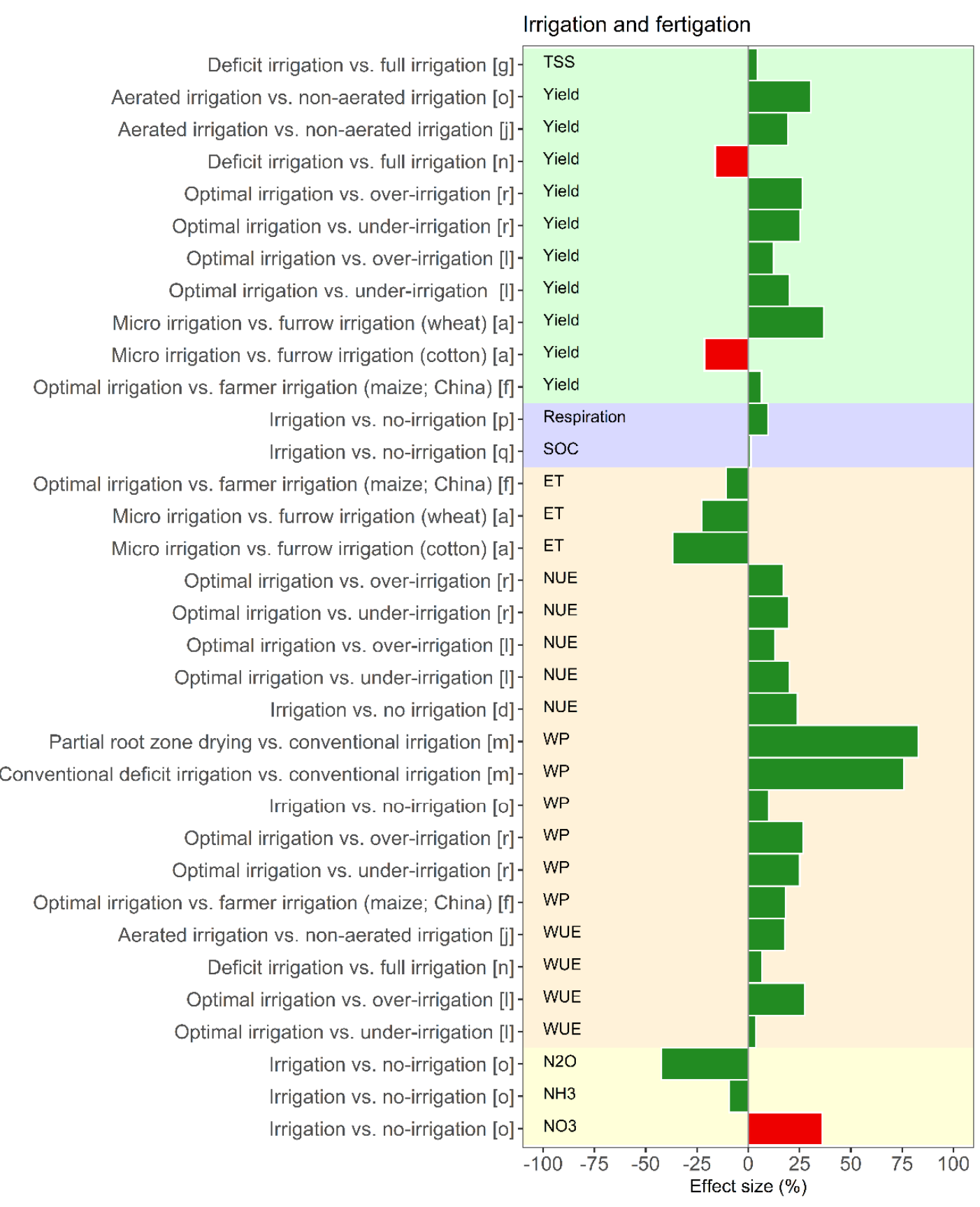

Figure 4. Overall response ratios reported in meta-analysis studies on irrigation and fertigation grouped per area of interest (light green: agronomic; light blue: soil quality; light orange: resource use efficiency; light brown: economic (no data); light yellow: environmental impacts). The management or treatment comparison is indicated outside the $y$-axis and the variable to which the data refer are listed inside the $y$-axis (abbreviations can be found in Table A1). Green bars indicate improvement, red bars indicate worsening. See also Table S3. [a]: [94]; [b]: [90]; [c]: [95]; [d]: [96]; [e]: [91]; [f]: [97]; [g]: [98]; [h]: [99]; [i]: [89]; [j]: [100]; [k]: [101]; [1]: [88]; [m]: [102]; [n]: [103]; [o]: [104]; [p]: [92]; [q]: [93]; [r]: [70]. 
Two meta-analysis studies examined the effects of irrigation method on emissions of $\mathrm{N}_{2} \mathrm{O}[89,90]$, while one study examined flood irrigation practices on emissions of methane from paddy rice [91]. Two studies examined effect of irrigation on soil respiration and soil carbon contents [92,93]. Only two studies pointed at large effects of interactions between irrigation and fertilization in water use efficiency and nutrient use efficiency [70,88].

\subsection{Controlled Drainage}

Effects of controlled drainage on the loss of water, nutrients, and greenhouse gases were assessed through six meta-analysis studies (Table 1). Controlled drainage is defined as the use of adjustable head structures to prevent discharge when the water table is lower than the outlet elevation. In this way the loss of water and nutrients may be altered, depending on the target. The quantitative effects of controlled drainage on reducing drainage volumes, $\mathrm{N}$ losses, and methane emissions were relatively large (range 17 to $85 \%$ ) (Table 2). Generally, controlled drainage resulted in reduced drainage volumes, depending on soil type [105]. Controlled drainage also reduced N-losses via drainage water to surface water [106-108] and methane $\left(\mathrm{CH}_{4}\right)$ emissions from peat lands [109]. No impact on yield was found by [108]. Alternating wetting and drying cycles in paddy rice greatly decreased $\mathrm{CH}_{4}$ emissions, but increased $\mathrm{N}_{2} \mathrm{O}$ emission; yet total greenhouse gas emissions decreased through improved water management [110].

Table 2. Controlled drainage: effect sizes as reported in meta-analysis studies. See also Table S4.

\begin{tabular}{ccc}
\hline Parameter & Comparison of Treatments & Main Results \\
\hline Yield & Drainage vs. none & not significant [e] \\
Economic benefit & Drainage vs. none & 9 to $37 \$$ ha $^{-1} \mathrm{yr}^{-1}[\mathrm{c}]$ \\
CH4 emission from & Wetting and drying vs. & $-35 \%[\mathrm{f}]$ \\
paddy rice field & continuous flooding & $-29 \%$ for CH4+N2O (net GWP) [f] \\
CH4 emission from peat & Drainage vs. none & $-84 \%[\mathrm{a}]$ \\
Drainage volume & Drainage vs. none & $-47 \%[\mathrm{~b}] ;-17 \%$ to $-85 \%[\mathrm{~d}] ;-19 \%[\mathrm{e}]$ \\
N-load & Drainage vs. none & $-41 \%[\mathrm{c}] ;-18 \%$ to $-85 \%[\mathrm{~d}] ;-32 \%[\mathrm{e}]$ \\
P-load & Drainage vs. none & $-19 \%[\mathrm{e}]$ \\
\hline
\end{tabular}

[a]: [109]; [b]: [105]; [c]: [106]; [d]: [107]; [e]: [108]; [f]: [110].

\subsection{Tillage}

Tillage refers to the preparation of the soil for growing crops, with or without incorporation of crop residues in the soil and/or weed control. In conventional or traditional tillage (TT), the topsoil (usually the upper 15 to $25 \mathrm{~cm}$ ) is turned and/or milled. Conservation tillage (including no-tillage (NT) or reduced tillage (RT)) is the practice of minimizing soil disturbance, whereby crop residues commonly remain on the soil surface to protect the soil, while herbicides or precision mechanical weeding tools are used to control weeds. Tillage practices are debated because of high fossil energy and labor costs, and their effects on soil erosion, crop yield, soil organic carbon, and soil biodiversity. This debate is reflected in the high number (55) of meta-analysis studies (Table 1). The focus of most meta-analysis studies has been on soil quality (36), followed by crop yield effects (19) and environmental effects (14). Two studies synthesized economic implications of different tillage practices (Table 1). Of the total number of studies, 20 were global studies, 14 studies related to (parts of) China, 5 to the Mediterranean, 3 to US, 1 to South Asia, 1 to Brazil, 1 to Europe and none to Africa.

Overall, conservation tillage decreased crop yields, increased soil organic carbon contents in the topsoil, increased soil biodiversity and the abundance of soil organisms, and increased $\mathrm{N}_{2} \mathrm{O}$ emissions relative to conventional tillage, but the magnitude of the differences depended on climate and the particular study (Figure 5). Yield penalties of no-till depended on crop residue return and crop rotation and were larger in tropical than temperate regions, and tended to decrease with an increase in the duration of no-till [22,111]. The South-Asian study was probably the most integrated one, as it examined effect sizes of crop yield, water use, soil organic $C$ sequestration, emissions of $\mathrm{CO}_{2}, \mathrm{CH}_{4}$, and $\mathrm{N}_{2} \mathrm{O}$, 
and economic costs [112]. The cost of production was significantly lower under no-till than under conventional tillage in all the selected crops, and the net economic returns increased by 5 to $32 \%$. Manley et al. [113] examined the economic cost of soil carbon sequestration in the US through no-till. They found that the additional carbon sequestration of no-till compared to conventional till was small and variable, and as a result, the net economic benefit also varied widely.

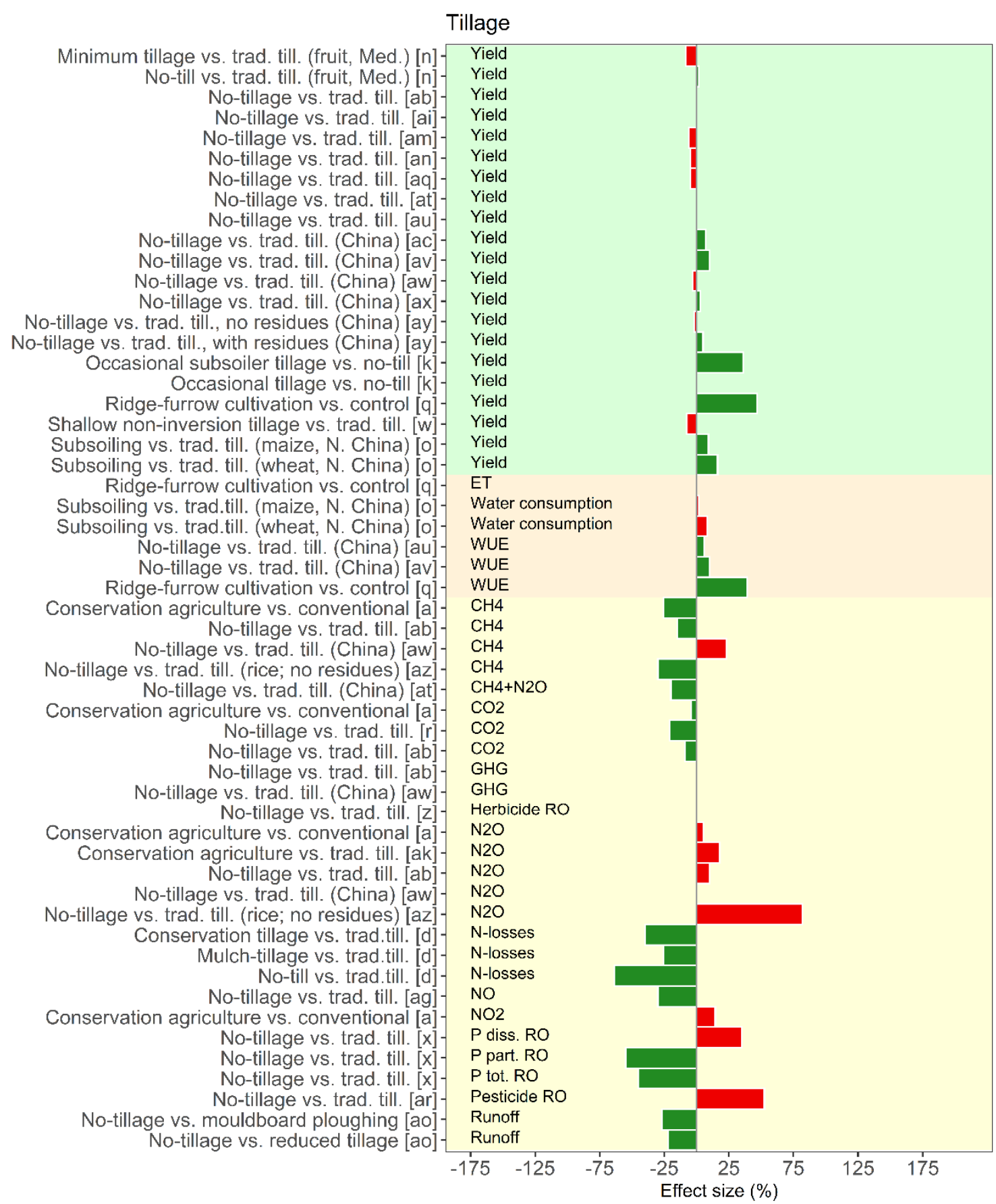

Figure 5. Cont. 


\section{Tillage}

Occasional tillage vs. no-till [k] Low-intensity tillage vs. trad. till. [u] No-tillage vs. trad. till. [u] Reduced tillage vs. trad. till. [g] No-till vs. trad. till. [p] No-tillage vs. trad. till. [af] No-till vs. trad. till. [y]

Conservation tillage (NT, RT) vs. trad. till. [f] No-till vs. trad. till. [e] No-till vs. trad.till.

Reduced tillage vs. trad.till. No-till vs. trad.till. [p]

Conservation agriculture vs. trad. till. (Med.) [ac] Conservation agriculture vs. conventional [a] Conservation agriculture vs. trad. till. (Med.) [ac] No-tillage vs. trad. till. [af] No-tillage vs. trad. till. [t] Occasional tillage vs. no-till [k] No-till vs. trad.till. []

No-tillage vs. trad. till. [ae No-tillage vs. trad. till. [y] No-till vs. trad.till.

Conservation tillage (NT, RT) vs. trad.till. [f] No-till vs. trad.till. [e] No-till vs. trad till. [i]

Reduced tillage vs. trad.till. [i]

Occasional tillage vs. no-till [k] No-till vs. trad.till. [i]

Reduced tillage vs. trad.till. [g] No-tillage vs. trad. till. [ay]

Conservation agriculture vs. trad. till. [af] No-till vs. trad.till. [p] No-till vs. trad.till. No-till vs. trad.till.

Occasional tillage vs. no-till [k] Chisel vs. mouldboard plough [c] No-till vs. mouldboard plough [c]

Occasional tillage vs. no-till [k] Perennial vs. mouldboard plough [c] Chisel vs. mouldboard plough [c] No-till vs. mouldboard plough [c] Perennial vs. mouldboard plough [c] Conservation tillage (NT, RT) vs. trad.till. [ No-till vs. trad.till. [e

Occasional tillage vs. no-till [k] No-till vs. trad.till. [p

No-tillage vs. trad. till. [af]

Occasional tillage vs. no-till [k] No-till vs. trad.till.

Conservation tillage (NT, RT) vs. trad.till. [f] Minimum tillage vs. trad.till. (fruit, Med.) [n]

No-till vs. trad.till. (fruit, Med.) [n]
Aggrega

AMF richn

Arthropod predator

AWC

AWC

Bacteria

Bact. biomass

Bact. community

Bact. count

Bact. count

BD

Beta-glucose

C seq.

Dehydrog. act

$\mathrm{BD}$

BD

$\mathrm{BD}$

BD (5-10 cm)

EOC

Fauna div.

Field capacity $(0-5 \mathrm{~cm})$

Fungal biomass

Fungal community

Fungal count

Fungal count

Infiltration

Infiltration rate

Insect and slug pests

$\mathrm{K}$ avail.

Ksat

Ksat

$\operatorname{Lrv}(0-5 \mathrm{~cm})$

Lrv (other depths)

Macroporosity

MBC

MBC

$M B C$

$M B C$

$M B N$

MBN

MBN

Microbial biomass

Microbial community

Mulch cover

MWD

MWD

MWD

MWD $(0-5 \mathrm{~cm})$

$\mathrm{N}$ tot

$\mathrm{N}$ tot.

$\mathrm{N}$ tot.

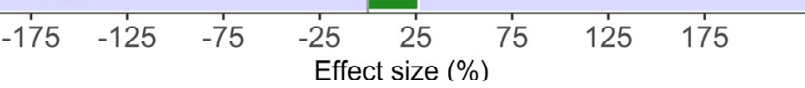

Figure 5. Cont. 


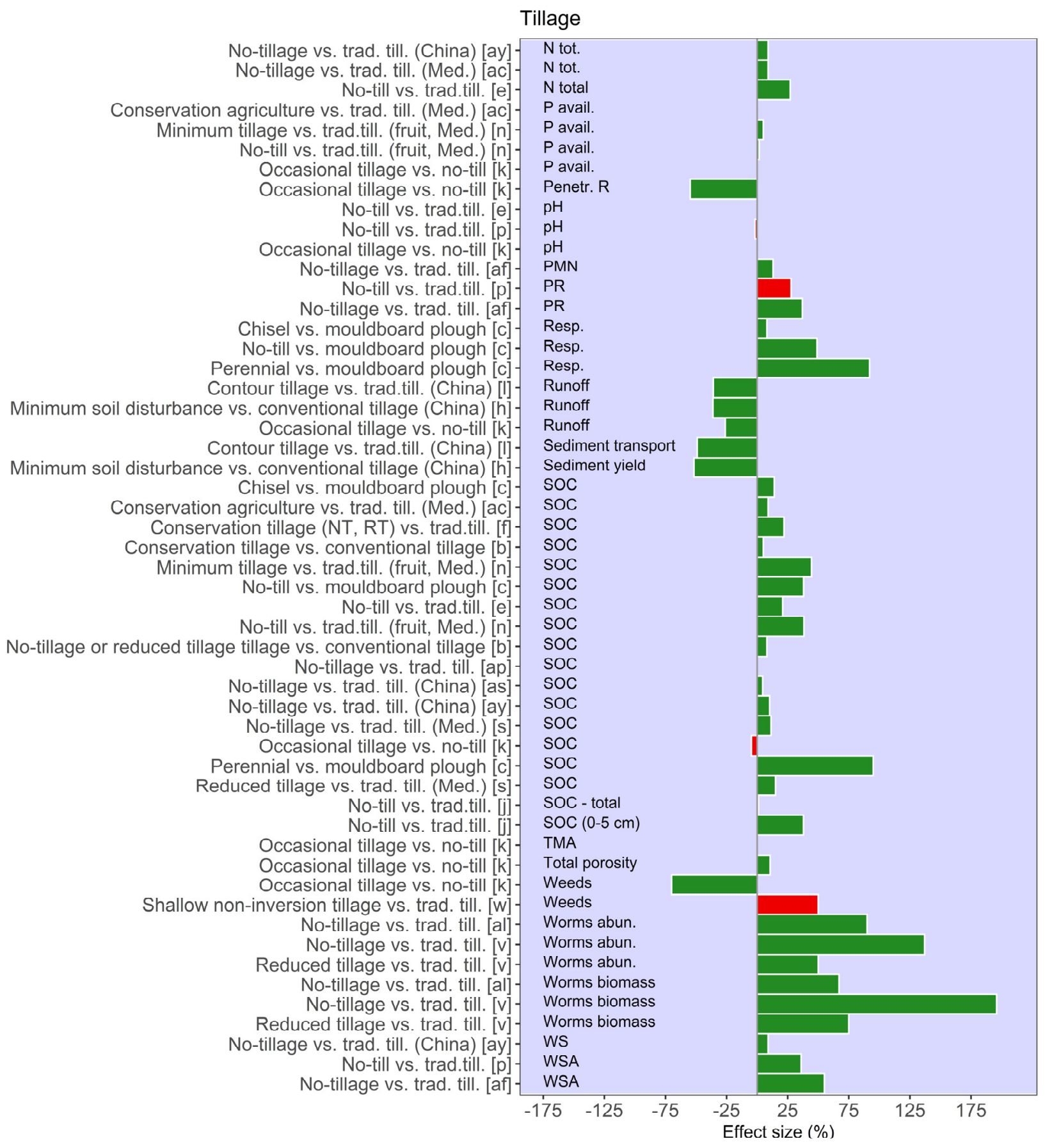

Figure 5. Overall response ratios reported in meta-analysis studies on tillage grouped per area of interest (light green: agronomic; light blue: soil quality; light orange: resource use efficiency; light brown: economic (no data); light yellow: environmental impacts). The management or treatment comparison is indicated outside the y-axis and the variable to which the data refer are listed inside the $\mathrm{y}$-axis (abbreviations can be found in Table A1). Green bars indicate improvement, red bars indicate worsening. See also Table S5. [a]: [112]; [b]: [61]; [c]: [123]; [d]: [123]; [e]: [124]; [f]: [125]; [g]: [124]; [h]: [120]; [i]: [115]; [j]: [118]; [k]: [119]; [1]: [126]; [m]: [127]; [n]: [63]; [o]: [128]; [p]: [129]; [q]: [130]; [r]: [131]; [s]: [132]; [t]: [133]; [u]: [49]; [v]: [114]; [w]: [134]; [x]: [53]; [y]: [135]; [z]: [122]; [aa]: [136]; [ab]: [137]; [ac]: [138]; [ad]: [139]; [ae]: [140]; [af]: [117]; [ag]: [74]; [ah]: [141]; [ai]: [142]; [aj]: [113]; [ak]: [143]; [al]: [116]; [am]: [111]; [an]: [22]; [ao]: [121]; [ap]: [144]; [aq]: [24]; [ar]: [145]; [as]: [146]; [at]: [147]; [au]: [148]; [av]: [149]; [aw]: [150]; [ax]: [151]; [ay]: [152]; [az]: [153]. 
Several studies found positive effect sizes of no-till versus conventional till for number of earthworms and for the diversity of the (micro) biological community (e.g., [114-116]). No-till tended to increase the bulk density in the lower part of the topsoil $(10-20 \mathrm{~cm})$ and the water infiltration rate significantly $[117,118]$. However, no-till combined with occasional conventional tillage decreased soil bulk density compared to conventional tillage [119]. Effects of no-till on erosion are strongly affected by crop type and soil surface mulching; on average no-till and conservation agriculture reduced erosion $[120,121]$, but pesticides in runoff tended to increase [122].

\subsection{Pest Management}

Pest management refers to the control of the number of undesirable organisms (pathogens, pest organisms) below an acceptable threshold, which is often based on economic principles. Methods of control can be crop rotation, chemical, biological, physi$\mathrm{cal} / \mathrm{mechanical}$, and/or genetic. There are often interactions with crop residue management, tillage, nutrient management, irrigation, and landscape management [154]. We found seven meta-analysis studies related to pest management (Table 1), of which three were in the context of comparing organic versus conventional agriculture (Table 3). Muneret et al. [155] found that organic farming experiences higher levels of pest infestation, but is able to match or outperform conventional pest control practices against plant pathogens and animal pests. Lesur-Dumoulin et al. [156] found that yields in organic horticulture were on average 10 to $32 \%$ lower than yields in conventional horticulture (Table 3). Garratt et al. [157] observed that organic farming practices can increase natural enemy numbers and also pest responses. Fertilization tends to increase insects and fungal plant pathogens [158,159]. Biofumigation through incorporating Brassicaceae plants and crop residues, which release glucosinolates and isothiocyanates, in soil reduced pest abundance and subsequently increased crop yield by $30 \%$ [160]. Anaerobic soil disinfestation, through temporal soil sealing following incorporation of labile organic carbon in the soil, is also effective against soil borne pathogens [161]. Furthermore, it has been indicated that addition of organic amendments and improving soil quality and biodiversity may result in fewer pests [162].

Table 3. Pest management: main effects as reported in meta-analysis studies. See also Table S6.

\begin{tabular}{ccc}
\hline Parameter & Management Practices & Result \\
\hline Yield & Biofumigation & Abs. diff.: 29\% [a] \\
Yield & Anaerobic soil disinfestation & Abs. diff.: $30 \%[\mathrm{~b}]$ \\
Yield & Anaerobic soil disinfestation & Abs. diff.: $70 \%[\mathrm{~b}]$ \\
Suppression of pathogens & Organic/conventional & Ratio: 0.83 [c] \\
$\begin{array}{c}\text { Disease severity response by } \\
\text { fungal plant pathogens }\end{array}$ & Fertilized vs. unfertilized & Increase $0.3 \pm 0.1[\mathrm{~d}]$ \\
$\begin{array}{c}\text { Change in insect population } \\
\text { Change in pest population }\end{array}$ & Fertilization & Increase/decrease $175 / 78[\mathrm{e}]$ \\
\hline [a]: [160]; [b]: [161]; [c] [156]; [d]: [159]; [e]: [158]; [f]: [157]. & Increase/decrease 42/26 [f] \\
\hline
\end{tabular}

\subsection{Weed Management}

Weed management refers to the control of the number of weed plants (especially noxious weeds) to below an acceptable threshold, as weeds compete with the crop for light, water and nutrients. Weed management often includes a number of methods, including crop rotation/intercropping/cover crops, soil cultivation (weeding, hoeing), mulching (crop residues or plastic covers), herbicides spraying, and burning. We found four metaanalysis studies related to weed control (Table 2).

Verret et al. [163] found that intercropping with legume companion plants enhanced weed control, generally without reducing the yield of the main crop (Table 4). Cover crops can also decrease the incidence of weeds and may have other ecosystem services [164]. Crop rotation with different planting dates and crop diversification, combined with limited soil disturbance, can disrupt weed-crop associations in addition to reducing yield loss and rebuilding soil fertility [165-167]. Glyphosate is the most used chemical weed control 
agent [168], but is debated because of its effects on soil biodiversity and soil microbial respiration [169] and human health [168].

Table 4. Weed management: main effects as reported in meta-analysis studies. See also Table S7.

\begin{tabular}{ccc}
\hline Parameter & Comparison of Treatments & Result \\
\hline Weed biomass & $\begin{array}{c}\text { Legume intercropping vs. } \\
\text { conventional, both non-weeded } \\
\text { and weeded }\end{array}$ & $-56 \%,-42 \%[\mathrm{a}]$ \\
Weed density, biomass & Cover crops vs. traditional tillage & $-10 \%,-5 \%$, \\
Parasitic nematodes & Reduced tillage vs. & $+29 \%$ [b] \\
Number of studies with & traditional tillage & +40 and -7 out of 78 studies [c] \\
increase soil organic matter & Goil microbial respiration \\
Soil microbial biomass & Glyphosate vs. no use, $<10 \mathrm{mg} \mathrm{kg}$ & logarithm of ratio: \\
\hline [a]: [163]; [b]: [53]; [c]: [170]; [d]: [169].
\end{tabular}

\subsection{Crop Residue Management}

Crop residues may be left on the soil surface, incorporated in the soil, burned or removed from the field for use as livestock feed or biofuel. Evidently, there are trade-offs in managing crop residues [171]. Conservation agriculture promotes the return of the crop residues to the soil to increase soil quality and reduce soil erosion, often in combination with zero-tillage or reduced tillage (Section 3.6). In this review, we distinguished crop residue management as a separate management practice, because of the relatively large number (19) of meta-analysis studies related to just crop residues (Table 1). Crop yield, water and nitrogen use efficiency, emissions of $\mathrm{N}_{2} \mathrm{O}$, and soil carbon sequestration were the main topics of these studies.

In most cases, crop residue management and mulching increased crop yields, and water and nitrogen use efficiencies by 0 to 50\% (Figure 6). Mulching greatly reduced soil evaporation and thereby provided a greater fraction of soil water to the crop, which boosted crop yields. Crop residue return has a positive effect on soil carbon sequestration and soil microbial activity, but $\mathrm{N}_{2} \mathrm{O}$ emissions increased as well. Nine out of the 19 meta-analysis studies dealt with soil mulching effects in China, as it is a common practice in dry-land farming in China (and India). One study examined the performance of biodegradable plastics to determine the optimal type of mulching for maize, wheat, potato, and cotton [172], and another [173] compared the performance of biodegradable films relative to polyethylene films.

\subsection{Mechanization}

Mechanization has greatly increased labor productivity in modern crop production systems, especially during the last century, and thereby has greatly contributed to farmscale enlargement and withdrawal of labor from agriculture [189]. However, mechanization has also contributed to increased fossil fuel use and increased soil compaction [190]. During the last decades, research emphasis has shifted to precision technology, controlled traffic, and robotization. However, only two meta-analysis studies have touched mechanization, precision technology and robotization (Table 1). Ampoorter et al. [191] concluded on the basis of an analysis of 11 studies with 35 forest stands that mechanical harvesting of trees has led to the compaction of the top $30 \mathrm{~cm}$ of forest soils, with the largest effects on the top $10 \mathrm{~cm}$. One study was of a different nature: It examined the change in the ratio of maize grain yield to labor input following the introduction of specific sustainable intensification practices technologies in sub-Saharan countries [192]. No firm conclusions could be derived because of lack of sufficient empirical studies. 
Crop residue and mulching

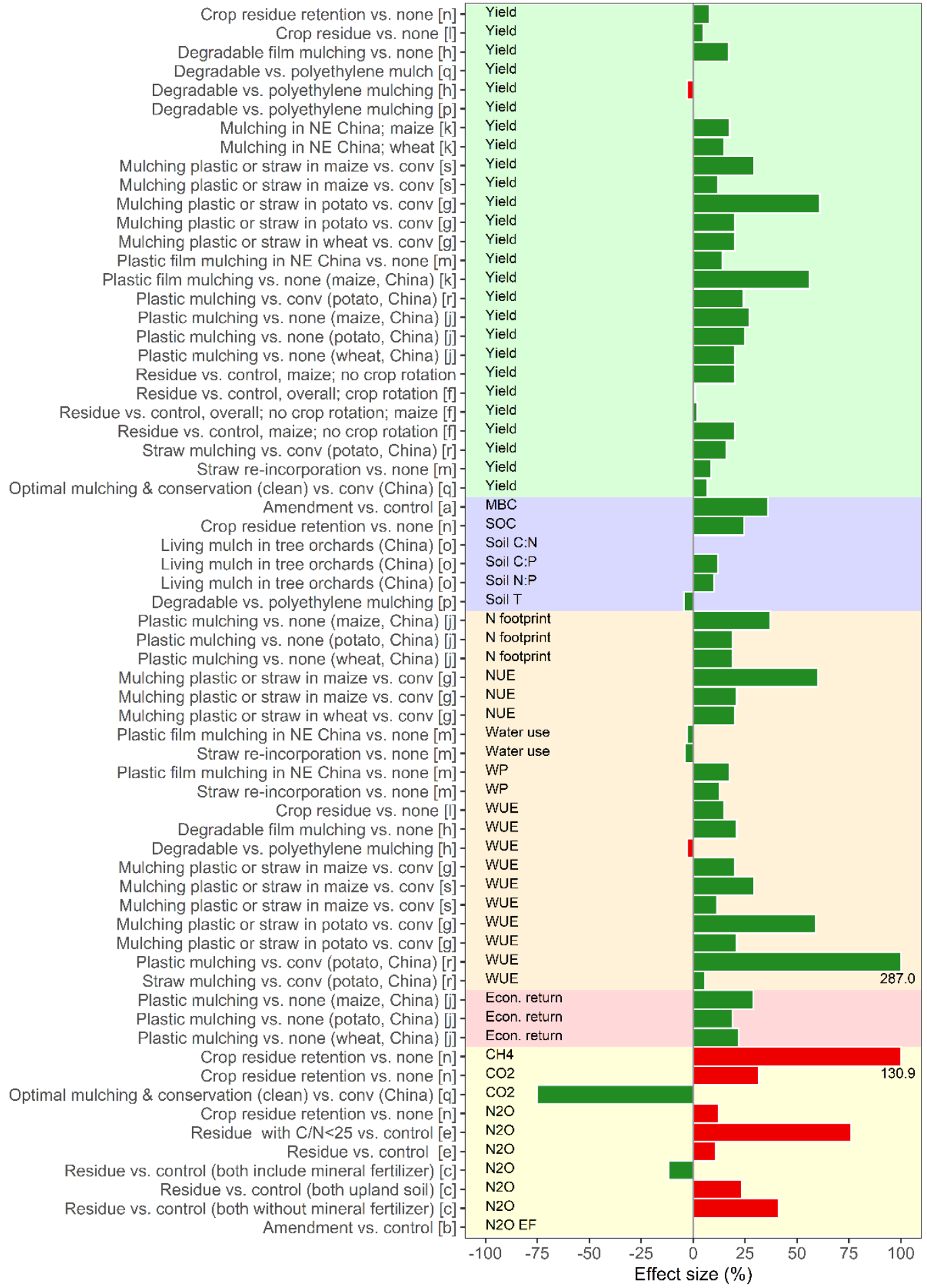

Figure 6. Overall response ratios reported in meta-analysis studies on crop residues and mulching grouped per area of interest (light green: agronomic; light blue: soil quality; light orange: resource use efficiency; light brown: economic; light yellow: environmental impacts). The management or treatment comparison is indicated outside the $y$-axis and the variable to which the data refer are listed inside the $y$-axis (abbreviations can be found in Table A1). Green bars indicate improvement, red bars indicate worsening. See also Table S8. [a]: [174]; [b] [175]; [c]: [176]; [d]: [177]; [e]: [178]; [f]: [22]; [g]: [179]; [h]: [172]; [i]: [180]; [j]: [181]; [k]: [182]; [1]: [183]; [m]: [97]; [n]: [184]; [o]: [185]; [p]: [173]; [q]: [186]; [r]: [187]; [s]: [188]. 


\subsection{Landscape Management}

Landscape management is a relatively new concept and has increased in importance following the approval of the UN Sustainable Development Goals and the recognition that the landscape is often the best scale for managing interactions, synergies, and tradeoffs for natural resource management [193-195]. Landscape management in the context of sustainable food production may include hydrological measures, terracing, hedgerows, tree lines, wind breaks, flower strips, corridors, and agroforestry, depending on the landscape, environmental conditions, and stakeholders.

We identified six meta-analysis studies related to landscape management practices (Tables 1 and 5). Three of these quantified the benefits of windbreaks on crop yields [196-198]. Three studies analyzed the effects of hedgerows and flower strips on pollination, pest control, and crop yield [197-199], and two studies analyzed the effects of hedgerows on runoff and erosion $[198,200]$. Both large positive effects and negative effects have been reported (Table 5).

Table 5. Landscape management: summary of the results as reported by meta-analysis studies. See also Table S9.

\begin{tabular}{|c|c|c|}
\hline Parameter & Management Practices & Result \\
\hline Crop yield increase & Wind breaks & $\begin{array}{c}\text { Spring wheat }+8 \% \text {, winter wheat }+23 \% \text {, } \\
\text { barley }+25 \% \text {, oats }+6 \% \text {, rye }+19 \% \text {, millet } \\
+44 \% \text {, corn }+12 \% \text {, alfalfa }+99 \% \text {, hay } \\
+20 \% \text { a] }\end{array}$ \\
\hline Crop yield & $\begin{array}{l}\text { Hedgerows vs. control; next to hedge } \\
\text { until twice the height; beyond twice the } \\
\text { height until } 20 \text { times the height }\end{array}$ & $-29 \%,+6 \%[b]$ \\
\hline Soil organic matter in crop field & Hedgerows vs. control & $6 \%[\mathrm{~b}]$ \\
\hline Interception of N, P, suspended solids from & Hedgerows & $69 \%, 67 \%, 91 \%[b]$ \\
\hline soil surface flow & Grass strips & $67 \%, 73 \%, 90 \%[b]$ \\
\hline Crop yield & Hedge rows, flower strips vs. none & ns [c] \\
\hline Pest control & Hedge rows, flower strips vs. none & $\mathrm{ns},-16 \%[\mathrm{c}]$ \\
\hline Pollination & Hedge rows, flower strips vs. none & $\mathrm{ns}[\mathrm{c}]$ \\
\hline Abundance, richness of pollinators in crop & Flower strips vs. none & ns, ns [d] \\
\hline Pollinator species richness & $\begin{array}{c}\text { Effect of agri-environment management, } \\
\text { type landscape: } \\
\text { Small, simple } \\
\text { Small, complex } \\
\text { Large, simple } \\
\text { Large, complex }\end{array}$ & $\begin{array}{l}\text { Hedge's d: } \\
\text { sign. [f] } \\
\text { ns [f] } \\
\text { sign. [f] } \\
\text { sign. [f] }\end{array}$ \\
\hline $\begin{array}{l}\text { Soil SOM, total } \mathrm{N} \text {, total } \mathrm{P} \text {, alkali } \mathrm{N} \text {, } \\
\text { available } \mathrm{P} \text {, readily available } \mathrm{K}, \\
\text { total } \mathrm{K}\end{array}$ & Hedge rows vs. none & $\begin{array}{l}\text { Hedge's d sign. [e] } \\
\text { Hedge's d ns [e] }\end{array}$ \\
\hline
\end{tabular}

[a]: [196]; [b]: [198]; [c]: [197]; [d]: [199]; [e]: [200]; [f]: [201].

\section{Discussion}

\subsection{Main Findings}

Most meta-analysis studies reported positive effects of alternative/improved practices relative to conventional practices. The 32 studies related to crop type and crop rotation clearly indicated the positive effects of crop rotations versus continuous cropping, legumes in crop rotations versus no legumes in crop rotations, intercropping versus monocultures, and cover cropping versus no cover cropping on crop yield and soil quality. Positive effects of especially cover crops and perennial crops on erosion control and minimizing nitrate leaching were also found, depending on, e.g., $\mathrm{N}$ fertilization.

The 25 studies related to nutrient management examined a diversity of nutrient sources, and application methods, timing, and strategies. Most studies reported positive effects of alternative/modified practices on crop yield and on minimizing environmental 
pollution, relative to conventional practices. Impacts of nutrient management strongly depended on environmental conditions.

The 18 studies related to irrigation and fertigation focused on the method, timing and volume of irrigation. Drip irrigation, deficit irrigation, and subsoil irrigation were all effective in increasing water use efficiency compared to sprinkling irrigation and especially flood irrigation. No economic assessments were made, and long-term impacts on soil quality and environmental pollution were also not reported.

Six studies related to drainage, with a focus on controlled drainage in response to variable rainfall patterns. Results indicate that controlled drainage increased farm income when compared to no human-induced drainage.

A total of 55 meta-analysis studies were devoted to tillage practices. Reduced tillage tended to reduce crop yields, but increased farm income (one study only), water use efficiency, soil carbon contents, and emissions of nitrous oxide $\left(\mathrm{N}_{2} \mathrm{O}\right)$, which is a potent greenhouse gas. Reduced tillage in combination with crop residue return (mulching) and crop rotation had a slight positive effect on crop yield compared to conventional tillage.

Most of the seven studies related to pest management compared organic farming and conventional farming management practices. In general, organic farming management practices greatly decreased the use of pesticides, but lowered crop yields as well, depending on crop type and rotation, $\mathrm{N}$ application rate, soil quality, and (soil) biodiversity.

The four studies related to weed management did not provide a coherent view. Legume intercropping, cover cropping, and reduced tillage had positive effects on soil carbon contents but the effects on weed and crop yield were not clear.

The 19 studies related to crop residue management and mulching in dryland and/or irrigated conditions reported in general positive effects of mulching on crop yield and water use efficiency, but also increases in $\mathrm{N}_{2} \mathrm{O}$ emissions, which are unwanted.

The six studies related to landscape management reported positive effects of windbreaks and hedgerows on crop yields and erosion control, but depending on site specific conditions, and provided that the surface area of windbreaks and hedgerows is in balance with the cropping area.

Evidently, most of the studies reported positive effects of the examined alternative/improved practices, relative to the common practice, on either crop yield, soil quality, resource use efficiency, and the environment (decreased emissions). While global assessment studies often paint rather pessimistic views on the state of food production, agriculture, and the environment $[10,16,202-204]$, it is clear that the 174 studies reviewed here present a picture of optimism and hope. Indeed, there is large body of scientific/empirical evidence that some specific practices are more effective than others, i.e., have positive effect sizes relative to conventional practices (Figures 1-6; Tables 2-5), and that these positive effects may contribute to the sustainability of crop and food production. However, large steps still have to be made to integrate, optimize, and transfer the scientific findings of meta-analysis in current practice. We note that only few meta-analysis studies examined interactions between categories of practices, while essentially no meta-analysis study made in-depth comparisons at cropping system level in which all ten categories of crop husbandry and soil management practices had been optimized. Hence, there is need for further integration and optimization of all ten crop husbandry and soil management practices, and show the effectiveness of optimized practices through experimental studies and ultimately meta-analysis studies. There is also a need to transfer the positive messages of meta-analysis studies to practice through demonstration, extension services and possibly economic incentives. Cropping systems with all crop husbandry and soil management practices optimized may be termed 'soil-improving cropping systems', to emphasize the two-way interaction between soil and crop (see Section 4.3).

\subsection{Uneven Coverage of Meta-Analysis Studies}

Some crop husbandry and soil management practices have been studied extensively and repeatedly, while some other practices have received little research attention (Table 1). 
Further, most studies have examined the effects of practices on crop yield, soil quality and environmental effects, while farm income (cost-benefit ratios) and resource use efficiency have received less attention (and human health aspects not at all). Evidently, the coverage of meta-analysis studies across practices and outcomes has been uneven; $75 \%$ of all studies addressed four practices, in the order: soil tillage $>$ crop type and crop rotations $>$ nutrient management $>$ irrigation/fertigation (Table 1).

The large interest in soil tillage (55 meta-analyses studies) is certainly related to the importance of soil conservation, and the envisaged reduction in soil erosion, net greenhouse gas emissions, energy use, and labor through minimum or zero tillage. The effect-size of tillage practices were relatively small (0-10\%) for crop yield, modest (0-50\%) for greenhouse gas emissions and nutrient leaching, and relatively large and positive for soil quality, especially for soil life (0-150\%).

The relatively large attention for nutrient management and irrigation/fertigation is related to the role of nutrients and water in boosting crop yields across the world (e.g., [205], to the depletion of fresh water resources [206] and rock phosphorus resources [207,208], and to the ecological impacts of excess nitrogen and phosphorus in the environment $[16,209])$. Nutrient and irrigation water inputs often form a relatively large economic cost to farmers, especially in developing countries, but this aspect has not been addressed.

We found only two meta-analyses related to mechanization and technology in agriculture (including forestry). However, several recent textbooks on precision technology for cropping systems do address the possible economic and environmental impacts of technological applications for sensing, field operations, and data handling, analysis, and control (e.g., [210-212]. Indeed, mechanization has revolutionized crop production systems during the past century but differently in different regions of the world. It has made large-scale crop production systems possible, has led to an exodus of laborers, has contributed to international trade of food and feed, and has indirectly affected essentially all crop husbandry and soil management practices. Robotization goes a step further and may revolutionize crop production systems again in the near future; it also offers the opportunity the reduce the impact of heavy machines on soil compaction. Keller et al. [190] estimated that the increase in weight of agricultural vehicles has caused an increase in soil bulk density, and thereby decreased root growth, crop yields, and soil hydraulic properties. They speculate that heavy machinery has contributed to yield stagnation and increased flooding in Europe [190].

We recommend that future meta-analysis studies related to crop husbandry and soil management practices should pay more attention to the socio-economic impacts of practices including possible barriers and constraints for their implementation in practice. Next, we recommend that more emphasis has to be given to interactions between multiple crop husbandry and soil management practices, and to comparisons of region-specific optimized packages of these practices. Further, Africa should not be neglected, as much of the increased food demand (and food production) during the next few decades will occur in Africa.

\subsection{Towards High-Yielding, Soil-Improving, and Environmentally Sound Cropping Systems}

The effect of specific crop yield defining, yield limiting, or yield reducing factors is largest when all other crop yield defining, limiting, or reducing factors are optimal, i.e., at a level where these do not affect crop yield [213]. This 'law of the optimum' may have also influenced the outcomes of meta-analyses studies; optimality of all factors will have enhanced the effect size of an alternative practice relative to the control practice, and vice versa. We have no insight in the degree of optimality of yield factors in the studies underlying the reviewed meta-analyses, but simply note here that there is often a gap between actual and attainable yields, and between actual and attainable environmental performances in practice. These gaps have to be narrowed to be able to produce adequate amounts of food in a sustainable and region-specific way [214]. 
The reviewed meta-analysis studies provide many suggestions for improved practices, but the optimization of all practices has to be done for specific regions, at farm level and/or regional levels. The possible steps in the optimization process have been summarized in Figure 7; it provides a roadmap for developing high-yielding, soil-improving and environmental-sound cropping systems. Steps 1 and 2 deal with the analyses and description of the current cropping systems, including its socio-economic and environmental environments. Steps 3 to 12 then deal with the selection and optimization of the 10 main specific crop husbandry and soil management practices, while taking the results of steps 1 and 2 into account. The actual process of optimization will be iterative, until the most optimal combination of practices has been identified. Variants of this road-map have been tested within the EU-funded project SoilCare, and results are presented in this special issue.

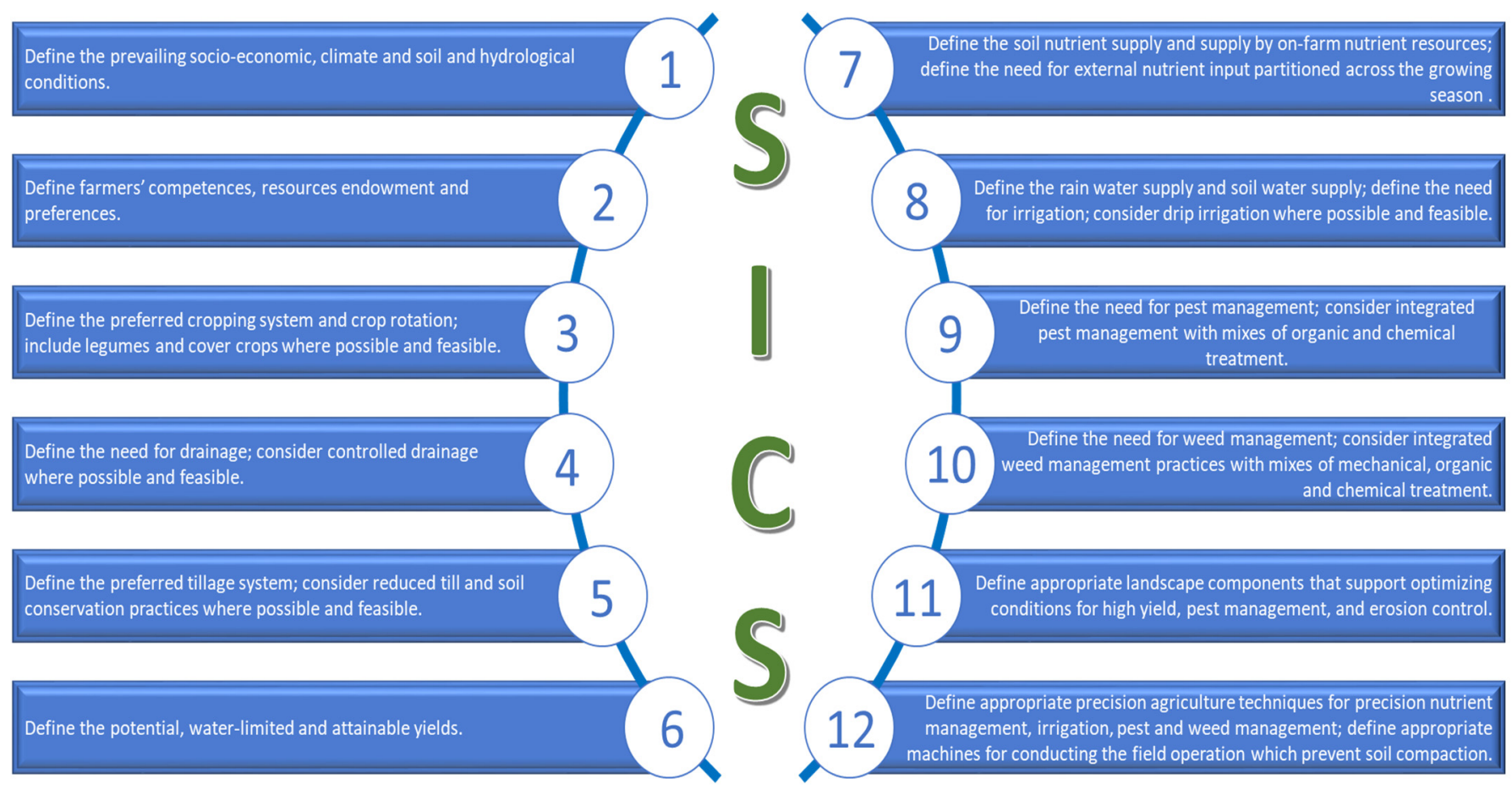

Figure 7. Towards sustainable cropping systems; a step-wise roadmap for developing high-yielding, soil-improving and environmentally sound cropping systems. The steps (1 to 12) have to be taken in a consecutive-iterative manner so as to find the optimal combination of practices.

\subsection{Concluding Remarks}

Crop husbandry and soil management practices are of critical importance for closing yield gaps, raising farm income and soil quality, and minimizing the environmental impacts of cropping systems in the world. We identified ten categories of crop husbandry and soil management practices, based on the concept of crop yield defining, limiting and reducing factors, and tried to quantify the effects of improved or modified practices relative to conventional practices, by using results of meta-analysis studies.

Our review was based on the premise that meta-analysis papers and reviews synthesize large numbers of experimental studies related to topical research questions and important research findings. For example, closing yield gaps and decreasing environmental impacts are topical, and thus we expected that in the course of the last 20 years when meta-analysis studies blossomed, a wealth of synthesized information would become accessible to help improve crop husbandry and soil management practices and thereby increase crop yield and soil quality, and decrease the environmental impact of crop production. The meta-analysis studies reviewed covered a huge number of experimental studies and practices in different parts of the world, albeit uneven. The number of studies per category 
of practices seem to reflect topics of hot societal debates and/or studies with controversial research findings. The number of meta-analysis studies per category of practices seem not to reflect those topics and practices that have largest impacts on crop yields, soil quality, and the environment.

Most meta-analysis studies reported positive effects of specific practices relative to conventional practices, on crop yield, soil quality and the environment. However, most meta-analysis studies examined single practices, with limited emphasis on interactions between categories of practices, and on the optimization across practices. Further, the coverage of studies was uneven, both in terms of practices, sustainability aspects and world regions. Notably, economic aspects were rarely addressed.

Based on this review, we derived a roadmap with twelve steps for integrating and optimization of all main crop husbandry and soil management practices, so as to develop high-yielding, soil-improving, and environmentally-sound cropping systems. We call these 'soil-improving cropping systems' to emphasize that cropping systems must maintain and improve soil quality to remain sustainable. This roadmap has been tested in practice and some results are presented in other papers of this special issue. We also made a number of recommendations.

Supplementary Materials: The following supporting information can be downloaded at: https: / / www.mdpi.com/article/10.3390/land11020255/s1, Table S1: Cropping: effects on (a) crop yield and quality, (b) soil quality, (c) economic effects, (d) resource use efficiency, (e) environmental effects, and (f) human health impacts as reported in meta analysis studies; aoi = area of interest. Table S2: Nutrient management: effects on (a) crop yield and quality, (b) soil quality, (c) economic effects, (d) resource use efficiency, (e) environmental effects, and (f) human health impacts as reported in meta analysis studies; aoi = area of interest. Table S3: Irrigation and fertigation: effects on (a) crop yield and quality, (b) soil quality, (c) economic effects, (d) resource use efficiency, (e) environmental effects, and (f) human health impacts as reported in meta analysis studies; aoi = area of interest. $\mathrm{DI}=$ deficit irrigation, $\mathrm{PRD}=$ partial rootzone drying, $\mathrm{FI}=$ full irrigation, $\mathrm{AI}=$ aerated irrigation, NAI non aerated irrigation, RDI = regulated deficit irrigation, $\mathrm{CDI}=$ conventional deficit irrigation, $\mathrm{CI}=$ conventional irrigation, $\mathrm{OI}=$ over irrigation, $\mathrm{UI}=$ under irrigation, $\mathrm{OPTI}=$ optimal irrigation . Table S4: Controlled drainage: effects on (a) crop yield and quality, (b) soil quality, (c) economic effects, (d) resource use efficiency, (e) environmental effects, and (f) human health impacts as reported in meta analysis studies; aoi = area of interest (see Table 1). Table S5: Soil tillage: effects on (a) crop yield and quality, (b) soil quality, (c) economic effects, (d) resource use efficiency, (e) environmental effects, and (f) human health impacts as reported in meta analysis studies; aoi = area of interest. NT = no tillage, $\mathrm{TT}=$ traditional tillage, $\mathrm{CA}=$ conservation agriculture, $\mathrm{RT}=$ reduced tillage, $\mathrm{MT}=$ minimum tillage Table S6: Pest management: effects on (a) crop yield and quality, (b) soil quality, (c) economic effects, (d) resource use efficiency, (e) environmental effects, and (f) human health impacts as reported in meta analysis studies; aoi = area of interest. Table S7: Weed management: effects on (a) crop yield and quality, (b) soil quality, (c) economic effects, (d) resource use efficiency, (e) environmental effects, and (f) human health impacts as reported in meta analysis studies; aoi = area of interest. Table S8: Crop residue management \& mulching: effects on (a) crop yield and quality, (b) soil quality, (c) economic effects, (d) resource use efficiency, (e) environmental effects, and (f) human health impacts as reported in meta analysis studies; aoi = area of interest. Table S9: Landscape management: effects on (a) crop yield and quality, (b) soil quality, (c) economic effects, (d) resource use efficiency, (e) environmental effects, and (f) human health impacts as reported in meta analysis studies; aoi = area of interest. Table S10: Explanation of the main columns in the accompanying Excel sheet.

Author Contributions: Conceptualization and writing by all authors; data collection and data analysis by R.R. + M.H. (contributed equally to this study). Review and editing were done by all authors. All authors have read and agreed to the published version of the manuscript.

Funding: The present study was carried out in the EU project SoilCare ("Soil care for profitable and sustainable crop production in Europe"), EU grant agreement 677407; https: / www.soilcare-project.eu (accessed on 12 January 2022).

Institutional Review Board Statement: Not applicable. 
Informed Consent Statement: Not applicable.

Data Availability Statement: All tabulated data are available in the Supplemental Information (Word document with tables; Excel file with extended data).

Acknowledgments: This study builds on SoilCare report 07 (https://www.soilcare-project.eu/ resources/deliverables; accessed on 12 January 2022); we thank the co-authors of that report for their contributions.

Conflicts of Interest: The authors declare no conflict of interest.

\section{Appendix A}

Table A1. List of abbreviations.

\begin{tabular}{|c|c|c|c|}
\hline Abbreviation & Meaning & Abbreviation & Meaning \\
\hline abund. & Abundance & $\mathrm{N}_{2} \mathrm{O}$ & Nitrous oxide (emission) \\
\hline act. & Activity & $\mathrm{NH}_{3}$ & Ammonia (emission) \\
\hline AG activity & Activity of $\alpha-1,4$-glucosidase & $\mathrm{NO}_{3}$ & Nitrate (leaching) \\
\hline AMF & Arbuscular mycorrhizal fungi & NOx & Nitrogen oxides \\
\hline aoi & Area of interest & NUE & Nitrogen (nutrient) use efficiency \\
\hline AWC & Available water content & $\mathrm{OA}$ & Organic agriculture \\
\hline Bact. & Bacteria & OX activity & Oxidative decomposition \\
\hline $\mathrm{BD}$ & Dry bulk density & $\mathrm{P}$ & Phosphorus \\
\hline BG activity & Activity of $\beta-1,4$-glucosidase & part. & Particulate \\
\hline BX activity & Activity of $\beta-1,4$-xylosidase & Penetr. R & Penetration resistance \\
\hline $\mathrm{C}$ & Carbon & PEO activity & Peroxidase activity \\
\hline C-acq. activity & $\begin{array}{c}\text { Hydrolytic } \mathrm{C} \text { acquisition } \\
\text { enzymes }\end{array}$ & PHO activity & Phenol oxidase activity \\
\hline $\mathrm{CBH}$ activity & Activity of $\beta$-D-cellobiosidase & PLFA & Phospholipid fatty-acids \\
\hline $\mathrm{CH}_{4}$ & Methane & PMN & Potentially mineralizable $\mathrm{N}$ \\
\hline $\mathrm{CO}_{2}$ & Carbon dioxide emission & PR & Penetration resistance \\
\hline col. & Colonies & Resp. & Respiration \\
\hline Dehydrog. & Dehydrogenase activity & richn. & Richness \\
\hline Dens. herb. & Density herbivorous insects & $\mathrm{RO}$ & Runoff \\
\hline diss. & Dissolved & RR & Response ratio: $\mathrm{RR}=\left(\mathrm{X}_{\mathrm{t}}-\mathrm{X}_{\mathrm{c}}\right) / \mathrm{X}_{\mathrm{c}}$ \\
\hline div. & Diversity & SDG & Sustainable development goals \\
\hline Econ. return & Economic return & seq. & Sequestration \\
\hline EEA & Soil extracellular enzyme activity & SICS & Soil-improving cropping systems \\
\hline $\mathrm{EF}$ & Emission factor & SMB & Soil microbial biomass \\
\hline $\mathrm{EF}_{\mathrm{ad}}$ & Additional $\mathrm{N} 2 \mathrm{O}$ emission factor \# & SMC & Soil microbial C \\
\hline EOC & Extractable organic carbon & $\mathrm{SOC}$ & Soil organic C \\
\hline ET & Evapotranspiration or water use & Soil T & Soil temperature \\
\hline FNER & Fertilizer $N$ equivalent ratio & SOM & Soil organic matter \\
\hline GHG & Greenhouse gas & SON & Soil organic $\mathrm{N}$ \\
\hline GWP & Global warming potential ${ }^{\$}$ & SWA & Soil water-stable aggregate \\
\hline K & Potassium & TMA & Total microbial activity \\
\hline Ksat & Hydraulic conductivity at saturation & tot. & Total \\
\hline LER & Land equivalent ratio & TSS & Total soluble solids \\
\hline Lrv & Root length density & WP & Water productivity \\
\hline Max. econ. return & Maximum economic return & WS & Water storage \\
\hline $\mathrm{MBC}$ & Microbial biomass $C$ & WSA & Water stable aggregates \\
\hline $\mathrm{MBN}$ & Microbial biomass $\mathrm{N}$ & WUE & Water use efficiency \\
\hline MWD & Aggregate mean weight diameter & $\mathrm{Xc}_{\mathrm{c}}$ & Effect (value) of control treatment \\
\hline $\mathrm{N}$ & Nitrogen & $X \mathrm{t}$ & Effect (value) of specific treatment \\
\hline
\end{tabular}

\#: which is the conservation tillage-induced change in $\mathrm{N}_{2} \mathrm{O}$ emission compared to conventional tillage when $\mathrm{N}$ fertilizer is applied; $\$: \mathrm{CH}_{4}$ and $\mathrm{N}_{2} \mathrm{O}$ emissions per unit yield. 


\section{References}

1. Iizumi, T.; Kotoku, M.; Kim, W.; West, P.C.; Gerber, J.S.; Brown, M.E. Uncertainties of potentials and recent changes in global yields of major crops resulting from census- and satellite-based yield datasets at multiple resolutions. PLoS ONE 2018, 13, e0203809. [CrossRef] [PubMed]

2. Ray, D.K.; Ramankutty, N.; Mueller, N.D.; West, P.C.; Foley, J.A. Recent patterns of crop yield growth and stagnation. Nat Commun 2012, 3, 1293. [CrossRef] [PubMed]

3. Foley, J.A.; Ramankutty, N.; Brauman, K.A.; Cassidy, E.S.; Gerber, J.S.; Johnston, M.; Mueller, N.D.; O'Connell, C.; Ray, D.K.; West, P.C.; et al. Solutions for a cultivated planet. Nature 2011, 478, 337-342. [CrossRef] [PubMed]

4. $\quad$ Ray, D.K.; Mueller, N.D.; West, P.C.; Foley, J.A. Yield Trends Are Insufficient to Double Global Crop Production by 2050. PLoS ONE 2013, 8, e66428. [CrossRef] [PubMed]

5. Lobell, D.B.; Cassman, K.G.; Field, C.B. Crop Yield Gaps: Their Importance, Magnitudes, and Causes. Annu. Rev. Environ. Resour. 2009, 34, 179-204. [CrossRef]

6. Van Ittersum, M.K.; Cassman, K.G.; Grassini, P.; Wolf, J.; Tittonell, P.; Hochman, Z. Yield gap analysis with local to global relevance-A review. Field Crop. Res. 2013, 143, 4-17. [CrossRef]

7. Brisson, N.; Gate, P.; Gouache, D.; Charmet, G.; Oury, F.-X.; Huard, F. Why are wheat yields stagnating in Europe? A comprehensive data analysis for France. Field Crop. Res. 2010, 119, 201-212. [CrossRef]

8. Schauberger, B.; Ben-Ari, T.; Makowski, D.; Kato, T.; Kato, H.; Ciais, P. Yield trends, variability and stagnation analysis of major crops in France over more than a century. Sci. Rep. 2018, 8, 16865. [CrossRef]

9. Schils, R.; Olesen, J.E.; Kersebaum, K.-C.; Rijk, B.; Oberforster, M.; Kalyada, V.; Khitrykau, M.; Gobin, A.; Kirchev, H.; Manolova, V.; et al. Cereal yield gaps across Europe. Eur. J. Agron. 2018, 101, 109-120. [CrossRef]

10. Amundson, R.; Berhe, A.A.; Hopmans, J.W.; Olson, C.; Sztein, A.E.; Sparks, D.L. Soil science. Soil and human security in the 21st century. Science 2015, 348, 1261071. [CrossRef]

11. Cassman, K.G. Ecological intensification of cereal production systems: Yield potential, soil quality, and precision agriculture. Proc. Natl. Acad. Sci. USA 1999, 96, 5942-5959. [CrossRef]

12. Cassman, K.G.; Dobermann, A.; Walters, D.T.; Yang, H. Meeting cereal demand while protecting natural resources And improving environmental quality. Annu. Rev. Environ. Resour. 2003, 28, 315-358. [CrossRef]

13. Connor, D.J.; RLoomis, R.S.; Cassman, K.G. Crop Ecology_Productivity and Management in Agricultural Systems, 2nd ed.; Cambridge University Press: Cambridge, UK, 2011.

14. FAO; DWFI. Yield Gap Analysis of Field Crops-Methods and Case Studies; Sadras, V.O., Cassman, K.G.G., Grassini, P., Hall, A.J., Bastiaanssen, W.G.M., Laborte, A.G., Milne, A.E., Sileshi, G., Steduto, P., Eds.; FAO Water Reports No. 41; FAO: Rome, Italy, 2015.

15. Snyder, C.S.; Bruulsema, T.W.; Jensen, T.L.; Fixen, P.E. Review of greenhouse gas emissions from crop production systems and fertilizer management effects. Agric. Ecosyst. Environ. 2009, 133, 247-266. [CrossRef]

16. Steffen, W.; Richardson, K.; Rockstrom, J.; Cornell, S.E.; Fetzer, I.; Bennett, E.M.; Biggs, R.; Carpenter, S.R.; de Vries, W.; de Wit, C.A.; et al. Planetary boundaries: Guiding human development on a changing planet. Science 2015, 347, 1259855. [CrossRef] [PubMed]

17. Tilman, D.; Balzer, C.; Hill, J.; Befort, B.L. Global food demand and the sustainable intensification of agriculture. Proc. Natl. Acad. Sci. USA 2011, 108, 20260-20264. [CrossRef] [PubMed]

18. Bouma, J. Soil Security in Sustainable Development. Soil Syst. 2019, 3, 5. [CrossRef]

19. Gil, J.D.B.; Daioglou, V.; van Ittersum, M.; Reidsma, P.; Doelman, J.C.; van Middelaar, C.E.; van Vuuren, D.P. Reconciling global sustainability targets and local action for food production and climate change mitigation. Glob. Environ. Change 2019, 59 , 101983. [CrossRef]

20. Iizumi, T.; Sakai, T. The global dataset of historical yields for major crops 1981-2016. Sci. Data 2020, 7, 97. [CrossRef]

21. Wezel, A.; Casagrande, M.; Celette, F.; Vian, J.-F.; Ferrer, A.; Peigné, J. Agroecological practices for sustainable agriculture. A review. Agron. Sustain. Dev. 2013, 34, 1-20. [CrossRef]

22. Pittelkow, C.M.; Linquist, B.A.; Lundy, M.E.; Liang, X.; van Groenigen, K.J.; Lee, J.; van Gestel, N.; Six, J.; Venterea, R.T.; van Kessel, C. When does no-till yield more? A global meta-analysis. Field Crop. Res. 2015, 183, 156-168. [CrossRef]

23. Reckling, M.; Bergkvist, G.; Watson, C.A.; Stoddard, F.L.; Zander, P.M.; Walker, R.L.; Pristeri, A.; Toncea, I.; Bachinger, J. Trade-Offs between Economic and Environmental Impacts of Introducing Legumes into Cropping Systems. Front. Plant Sci. 2016, 7, 669. [CrossRef] [PubMed]

24. Van den Putte, A.; Govers, G.; Diels, J.; Gillijns, K.; Demuzere, M. Assessing the effect of soil tillage on crop growth: A meta-regression analysis on European crop yields under conservation agriculture. Eur. J. Agron. 2010, 33, 231-241. [CrossRef]

25. Gurevitch, J.; Koricheva, J.; Nakagawa, S.; Stewart, G. Meta-analysis and the science of research synthesis. Nature 2018, 555, 175-182. [CrossRef] [PubMed]

26. O'Rourke, K. An historical perspective on meta-analysis: Dealing quantitatively with varying study results. J. R. Soc. Med. 2007, 100, 579-582. [CrossRef]

27. Angus, J.F.; Kirkegaard, J.A.; Hunt, J.R.; Ryan, M.H.; Ohlander, L.; Peoples, M.B. Break crops and rotations for wheat. Crop. Pasture Sci. 2015, 66, 523-552. [CrossRef]

28. Preissel, S.; Reckling, M.; Schläfke, N.; Zander, P. Magnitude and farm-economic value of grain legume pre-crop benefits in Europe: A review. Field Crop. Res. 2015, 175, 64-79. [CrossRef] 
29. Andert, S.; Bürger, J.; Stein, S.; Gerowitt, B. The influence of crop sequence on fungicide and herbicide use intensities in North German arable farming. Eur. J. Agron. 2016, 77, 81-89. [CrossRef]

30. Li, C.; Hoffland, E.; Kuyper, T.W.; Yu, Y.; Zhang, C.; Li, H.; Zhang, F.; van der Werf, W. Syndromes of production in intercropping impact yield gains. Nat. Plants 2020, 6, 653-660. [CrossRef]

31. Tonitto, C.; David, M.B.; Drinkwater, L.E. Replacing bare fallows with cover crops in fertilizer-intensive cropping systems: A meta-analysis of crop yield and N dynamics. Agric. Ecosyst. Environ. 2006, 112, 58-72. [CrossRef]

32. Valkama, E.; Lemola, R.; Känkänen, H.; Turtola, E. Meta-analysis of the effects of undersown catch crops on nitrogen leaching loss and grain yields in the Nordic countries. Agric. Ecosyst. Environ. 2015, 203, 93-101. [CrossRef]

33. Zhang, C.; Dong, Y.; Tang, L.; Zheng, Y.; Makowski, D.; Yu, Y.; Zhang, F.; van der Werf, W. Intercropping cereals with faba bean reduces plant disease incidence regardless of fertilizer input; a meta-analysis. Eur. J. Plant Pathol. 2019, 154, 931-942. [CrossRef]

34. Vannoppen, W.; Vanmaercke, M.; De Baets, S.; Poesen, J. A review of the mechanical effects of plant roots on concentrated flow erosion rates. Earth-Sci. Rev. 2015, 150, 666-678. [CrossRef]

35. Munkholm, L.J.; Heck, R.J.; Deen, B. Long-term rotation and tillage effects on soil structure and crop yield. Soil Tillage Res. 2013, 127, 85-91. [CrossRef]

36. Kiær, L.P.; Skovgaard, I.M.; Østergård, H. Grain yield increase in cereal variety mixtures: A meta-analysis of field trials. Field Crop. Res. 2009, 114, 361-373. [CrossRef]

37. Finn, J.A.; Kirwan, L.; Connolly, J.; Sebastià, M.T.; Helgadottir, A.; Baadshaug, O.H.; Bélanger, G.; Black, A.; Brophy, C.; Collins, R.P.; et al. Ecosystem function enhanced by combining four functional types of plant species in intensively managed grassland mixtures: A 3-year continental-scale field experiment. J. Appl. Ecol. 2013, 50, 365-375. [CrossRef]

38. Sainju, U.M. A global meta-analysis on the impact of management practices on net global warming potential and greenhouse gas intensity from cropland soils. PLoS ONE 2016, 11, e0148527. [CrossRef]

39. Han, Z.; Walter, M.T.; Drinkwater, L.E. $\mathrm{N}_{2} \mathrm{O}$ emissions from grain cropping systems: A meta-analysis of the impacts of fertilizerbased and ecologically-based nutrient management strategies. Nutr. Cycl. Agroecosyst. 2017, 107, 335-355. [CrossRef]

40. West, T.O.; Post, W.M. Soil organic carbon sequestration rates by tillage and crop rotation: A global data analysis. Soil Sci. Soc. Am. J. 2002, 66, 1930-1946. [CrossRef]

41. McDaniel, M.D.; Tiemann, L.K.; Grandy, A.S. Does agricultural crop diversity enhance soil microbial biomass and organic matter dynamics? A meta-analysis. Ecol. Appl. 2014, 24, 560-570. [CrossRef]

42. Venter, Z.S.; Jacobs, K.; Hawkins, H.-J. The impact of crop rotation on soil microbial diversity: A meta-analysis. Pedobiologia 2016, 59, 215-223. [CrossRef]

43. Bedoussac, L.; Journet, E.-P.; Hauggaard-Nielsen, H.; Naudin, C.; Corre-Hellou, G.; Jensen, E.S.; Prieur, L.; Justes, E. Ecological principles underlying the increase of productivity achieved by cereal-grain legume intercrops in organic farming. A review. Agron. Sustain. Dev. 2015, 35, 911-935. [CrossRef]

44. Yu, Y.; Stomph, T.-J.; Makowski, D.; Zhang, L.; van der Werf, W. A meta-analysis of relative crop yields in cereal/legume mixtures suggests options for management. Field Crop. Res. 2016, 198, 269-279. [CrossRef]

45. Dassou, A.G.; Tixier, P. Response of pest control by generalist predators to local-scale plant diversity: A meta-analysis. Ecol. Evol. 2016, 6, 1143-1153. [CrossRef]

46. Tonhasca, A., Jr.; Byrne, D.N. The effects of crop diversification on herbivorous insects: A meta-analysis approach. Ecol. Entomol. 1994, 19, 239-244. [CrossRef]

47. Miguez, F.E.; Bollero, G.A. Review of Corn Yield Response under Winter Cover Cropping Systems Using Meta-Analytic Methods. Crop Sci. 2005, 45, 2318-2329. [CrossRef]

48. Poeplau, C.; Don, A. Carbon sequestration in agricultural soils via cultivation of cover crops-A meta-analysis. Agric. Ecosyst. Environ. 2015, 200, 33-41. [CrossRef]

49. Bowles, T.M.; Jackson, L.E.; Loeher, M.; Cavagnaro, T.R.; Nuñez, M. Ecological intensification and arbuscular mycorrhizas: A meta-analysis of tillage and cover crop effects. J. Appl. Ecol. 2017, 54, 1785-1793. [CrossRef]

50. Quemada, M.; Baranski, M.; Nobel-de Lange, M.N.J.; Vallejo, A.; Cooper, J.M. Meta-analysis of strategies to control nitrate leaching in irrigated agricultural systems and their effects on crop yield. Agric. Ecosyst. Environ. 2013, 174, 203-206. [CrossRef]

51. Vicente-Vicente, J.L.; García-Ruiz, R.; Francaviglia, R.; Aguilera, E.; Smith, P. Soil carbon sequestration rates under Mediterranean woody crops using recommended management practices: A meta-analysis. Agric. Ecosyst. Environ. 2016, 235, 204-214. [CrossRef]

52. Poeplau, C.; Don, A. Soil carbon changes under Miscanthus driven by C4accumulation and C3decompostion-Toward a default sequestration function. GCB Bioenergy 2014, 6, 327-338. [CrossRef]

53. Daryanto, S.; Wang, L.; Jacinthe, P.A. Meta-Analysis of Phosphorus Loss from No-Till Soils. J. Environ. Qual. 2017, 46, 1028-1037. [CrossRef] [PubMed]

54. Thapa, R.; Mirsky, S.B.; Tully, K.L. Cover Crops Reduce Nitrate Leaching in Agroecosystems: A Global Meta-Analysis. J. Environ. Qual. 2018, 47, 1400-1411. [CrossRef] [PubMed]

55. Nichols, V.; Martinez-Feria, R.; Weisberger, D.; Carlson, S.; Basso, B.; Basche, A. Cover crops and weed suppression in the U.S. Midwest: A meta-analysis and modeling study. Agric. Environ. Lett. 2020, 5, e20022. [CrossRef]

56. Zhao, J.; Yang, Y.; Zhang, K.; Jeong, J.; Zeng, Z.; Zang, H. Does crop rotation yield more in China? A meta-analysis. Field Crop. Res. 2020, 245, 107659. [CrossRef] 
57. Jian, J.; Lester, B.J.; Du, X.; Reiter, M.S.; Stewart, R.D. A calculator to quantify cover crop effects on soil health and productivity. Soil Tillage Res. 2020, 199, 104575. [CrossRef]

58. Shackelford, G.E.; Kelsey, R.; Dicks, L.V. Effects of cover crops on multiple ecosystem services: Ten meta-analyses of data from arable farmland in California and the Mediterranean. Land Use Policy 2019, 88, 104204. [CrossRef]

59. Xu, Z.; Li, C.; Zhang, C.; Yu, Y.; van der Werf, W.; Zhang, F. Intercropping maize and soybean increases efficiency of land and fertilizer nitrogen use; A meta-analysis. Field Crop. Res. 2020, 246, 107661. [CrossRef]

60. Lori, M.; Symnaczik, S.; Mäder, P.; De Deyn, G.; Gattinger, A. Organic farming enhances soil microbial abundance and activity-A meta-analysis and meta-Regression. PLoS ONE 2017, 12, e0180442. [CrossRef]

61. Bai, X.; Huang, Y.; Ren, W.; Coyne, M.; Jacinthe, P.A.; Tao, B.; Hui, D.; Yang, J.; Matocha, C. Responses of soil carbon sequestration to climate-smart agriculture practices: A meta-analysis. Glob. Change Biol. 2019, 25, 2591-2606. [CrossRef]

62. Basche, A.D.; DeLonge, M.S. Comparing infiltration rates in soils managed with conventional and alternative farming methods: A meta-analysis. PLoS ONE 2019, 14, e0215702. [CrossRef]

63. Morugán-Coronado, A.; Linares, C.; Gómez-López, M.D.; Faz, Á.; Zornoza, R. The impact of intercropping, tillage and fertilizer type on soil and crop yield in fruit orchards under Mediterranean conditions: A meta-analysis of field studies. Agric. Syst. 2020, 178, 102736. [CrossRef]

64. Fernandez, J.A.; DeBruin, J.; Messina, C.D.; Ciampitti, I.A. Late-season nitrogen fertilization on maize yield: A meta-analysis. Field Crop. Res. 2020, 247, 107586. [CrossRef]

65. Hijbeek, R.; van Ittersum, M.K.; ten Berge, H.F.M.; Gort, G.; Spiegel, H.; Whitmore, A.P. Do organic inputs matter-A meta-analysis of additional yield effects for arable crops in Europe. Plant Soil 2016, 411, 293-303. [CrossRef]

66. Luo, G.; Li, L.; Friman, V.-P.; Guo, J.; Guo, S.; Shen, Q.; Ling, N. Organic amendments increase crop yields by improving microbe-mediated soil functioning of agroecosystems: A meta-analysis. Soil Biol. Biochem. 2018, 124, 105-115. [CrossRef]

67. Li, Y.; Cui, S.; Chang, S.X.; Zhang, Q. Liming effects on soil pH and crop yield depend on lime material type, application method and rate, and crop species: A global meta-analysis. J. Soils Sediments 2019, 19, 1393-1406. [CrossRef]

68. Jaggard, K.W.; Qi, A.; Armstrong, M.J. A meta-analysis of sugarbeet yield responses to nitrogen fertilizer measured in England since 1980. J. Agric. Sci. 2009, 147, 287-301. [CrossRef]

69. Geisseler, D.; Scow, K.M. Long-term effects of mineral fertilizers on soil microorganisms-A review. Soil Biol. Biochem. 2014, 75, 54-63. [CrossRef]

70. Li, Y.; Li, Z.; Cui, S.; Chang, S.X.; Jia, C.; Zhang, Q. A global synthesis of the effect of water and nitrogen input on maize (Zea mays) yield, water productivity and nitrogen use efficiency. Agric. For. Meteorol. 2019, 268, 136-145. [CrossRef]

71. Sha, Z.; Ma, X.; Wang, J.; Lv, T.; Li, Q.; Misselbrook, T.; Liu, X. Effect of N stabilizers on fertilizer-N fate in the soil-crop system: A meta-analysis. Agric. Ecosyst. Environ. 2020, 290, 106763. [CrossRef]

72. Borchard, N.; Schirrmann, M.; Cayuela, M.L.; Kammann, C.; Wrage-Monnig, N.; Estavillo, J.M.; Fuertes-Mendizabal, T.; Sigua, G.; Spokas, K.; Ippolito, J.A.; et al. Biochar, soil and land-use interactions that reduce nitrate leaching and $\mathrm{N}_{2} \mathrm{O}$ emissions: A meta-analysis. Sci. Total Environ. 2019, 651, 2354-2364. [CrossRef]

73. Eden, M.; Gerke, H.H.; Houot, S. Organic waste recycling in agriculture and related effects on soil water retention and plant available water: A review. Agron. Sustain. Dev. 2017, 37, 11. [CrossRef]

74. Liu, S.; Lin, F.; Wu, S.; Ji, C.; Sun, Y.; Jin, Y.; Li, S.; Li, Z.; Zou, J. A meta-analysis of fertilizer-induced soil NO and combined $\mathrm{NO}+\mathrm{N}_{2} \mathrm{O}$ emissions. Glob. Change Biol. 2017, 23, 2520-2532. [CrossRef] [PubMed]

75. Nkebiwe, P.M.; Weinmann, M.; Bar-Tal, A.; Müller, T. Fertilizer placement to improve crop nutrient acquisition and yield: A review and meta-analysis. Field Crop. Res. 2016, 196, 389-401. [CrossRef]

76. Ti, C.; Xia, L.; Chang, S.X.; Yan, X. Potential for mitigating global agricultural ammonia emission: A meta-analysis. Environ. Pollut. 2019, 245, 141-148. [CrossRef]

77. Tran, D.T.Q.; Bradbury, M.I.; van Ogtrop, F.F.; Bozkurt, H.; Jones, B.J.; McConchie, R. Environmental drivers for persistence of Escherichia coli and salmonella in manure-amended soils: A meta-analysis. J. Food Prot. 2020, 83, 1268-1277. [CrossRef]

78. Zhang, X.; Fang, Q.; Zhang, T.; Ma, W.; Velthof, G.L.; Hou, Y.; Oenema, O.; Zhang, F. Benefits and trade-offs of replacing synthetic fertilizers by animal manures in crop production in China: A meta-analysis. Glob. Change Biol. 2020, 26, 888-900. [CrossRef]

79. Li, W.; Yang, M.; Wang, J.; Wang, Z.; Fan, Z.; Kang, F.; Wang, Y.; Luo, Y.; Kuang, D.; Chen, Z.; et al. Agronomic responses of major fruit crops to fertilization in China: A meta-analysis. Agronomy 2020, 10, 15. [CrossRef]

80. Du, Y.; Cui, B.; Zhang, Q.; Wang, Z.; Sun, J.; Niu, W. Effects of manure fertilizer on crop yield and soil properties in China: A meta-analysis. Catena 2020, 193, 104617. [CrossRef]

81. Jian, S.; Li, J.; Chen, J.; Wang, G.; Mayes, M.A.; Dzantor, K.E.; Hui, D.; Luo, Y. Soil extracellular enzyme activities, soil carbon and nitrogen storage under nitrogen fertilization: A meta-analysis. Soil Biol. Biochem. 2016, 101, 32-43. [CrossRef]

82. Ye, G.; Lin, Y.; Luo, J.; Di, H.J.; Lindsey, S.; Liu, D.; Fan, J.; Ding, W. Responses of soil fungal diversity and community composition to long-term fertilization: Field experiment in an acidic Ultisol and literature synthesis. Appl. Soil Ecol. 2020, 145, 103305. [CrossRef]

83. He, M.; Zhou, G.; Yuan, T.; van Groenigen, K.J.; Shao, J.; Zhou, X. Grazing intensity significantly changes the C: N: P stoichiometry in grassland ecosystems. Glob. Ecol. Biogeogr. 2020, 29, 355-369. [CrossRef]

84. Quinn, D.J.; Lee, C.D.; Poffenbarger, H.J. Corn yield response to sub-surface banded starter fertilizer in the U.S.: A meta-analysis. Field Crop. Res. 2020, 254, 107834. [CrossRef] 
85. Liu, S.; Wang, J.; Pu, S.; Blagodatskaya, E.; Kuzyakov, Y.; Razavi, B.S. Impact of manure on soil biochemical properties: A global synthesis. Sci. Total Environ. 2020, 745, 141003. [CrossRef] [PubMed]

86. Emmerling, C.; Krein, A.; Junk, J. Meta-analysis of strategies to reduce $\mathrm{NH}_{3}$ emissions from slurries in European agriculture and consequences for greenhouse gas emissions. Agronomy 2020, 10, 1633. [CrossRef]

87. Foged, H.; Flotats Ripoll, X.; Bonmatí Blasi, A.; Palatsi Civit, J.; Magrí Aloy, A.; Schelde, K.M. Inventory of Manure Processing Activities in Europe; Technical Report No. I Concerning "Manure Processing Activities in Europe" to the European Commission; Directorate-General Environment: Brussels, Belgium, 2012; 138p.

88. Qin, W.; Assinck, F.B.T.; Heinen, M.; Oenema, O. Water and nitrogen use efficiencies in citrus production: A meta-analysis. Agric. Ecosyst. Environ. 2016, 222, 103-111. [CrossRef]

89. Cayuela, M.L.; Aguilera, E.; Sanz-Cobena, A.; Adams, D.C.; Abalos, D.; Barton, L.; Ryals, R.; Silver, W.L.; Alfaro, M.A.; Pappa, V.A.; et al. Direct nitrous oxide emissions in Mediterranean climate cropping systems: Emission factors based on a meta-analysis of available measurement data. Agric. Ecosyst. Environ. 2017, 238, 25-35. [CrossRef]

90. He, G.; Wang, Z.; Cui, Z. Managing irrigation water for sustainable rice production in China. J. Clean. Prod. 2020, $245,118928$. [CrossRef]

91. Jiang, Y.; Carrijo, D.; Huang, S.; Chen, J.; Balaine, N.; Zhang, W.; van Groenigen, K.J.; Linquist, B. Water management to mitigate the global warming potential of rice systems: A global meta-analysis. Field Crop. Res. 2019, 234, 47-54. [CrossRef]

92. Zhou, L.; Zhou, X.; Shao, J.; Nie, Y.; He, Y.; Jiang, L.; Wu, Z.; Hosseini Bai, S. Interactive effects of global change factors on soil respiration and its components: A meta-analysis. Glob. Change Biol. 2016, 22, 3157-3169. [CrossRef]

93. Zhou, X.; Zhou, L.; Nie, Y.; Fu, Y.; Du, Z.; Shao, J.; Zheng, Z.; Wang, X. Similar responses of soil carbon storage to drought and irrigation in terrestrial ecosystems but with contrasting mechanisms: A meta-analysis. Agric. Ecosyst. Environ. 2016, $228,70-81$. [CrossRef]

94. Fan, Y.; Wang, C.; Nan, Z. Determining water use efficiency of wheat and cotton: A meta-regression analysis. Agric. Water Manag. 2018, 199, 48-60. [CrossRef]

95. Mitchell-McCallister, D.; Cano, A.; West, C. Meta-analysis of crop water use efficiency by irrigation system in the Texas High Plains. Irrig. Sci. 2020, 38, 535-546. [CrossRef]

96. Liu, B.-Y.; Zhao, X.; Li, S.-S.; Zhang, X.-Z.; Virk, A.L.; Qi, J.-Y.; Kan, Z.-R.; Wang, X.; Ma, S.-T.; Zhang, H.-L. Meta-analysis of management-induced changes in nitrogen use efficiency of winter wheat in the North China Plain. J. Clean. Prod. 2020, 251, 119632. [CrossRef]

97. Zheng, H.; Shao, R.; Xue, Y.; Ying, H.; Yin, Y.; Cui, Z.; Yang, Q. Water productivity of irrigated maize production systems in Northern China: A meta-analysis. Agric. Water Manag. 2020, 234, 106119. [CrossRef]

98. Adu, M.O.; Yawson, D.O.; Abano, E.E.; Asare, P.A.; Armah, F.A.; Opoku, E.K. Does water-saving irrigation improve the quality of fruits and vegetables? Evidence from meta-analysis. Irrig. Sci. 2019, 37, 669-690. [CrossRef]

99. Adu, M.O.; Yawson, D.O.; Armah, F.A.; Asare, P.A.; Frimpong, K.A. Meta-analysis of crop yields of full, deficit, and partial root-zone drying irrigation. Agric. Water Manag. 2018, 197, 79-90. [CrossRef]

100. Du, Y.-D.; Niu, W.-Q.; Gu, X.-B.; Zhang, Q.; Cui, B.-J.; Zhao, Y. Crop yield and water use efficiency under aerated irrigation: A meta-analysis. Agric. Water Manag. 2018, 210, 158-164. [CrossRef]

101. Lu, J.; Shao, G.; Cui, J.; Wang, X.; Keabetswe, L. Yield, fruit quality and water use efficiency of tomato for processing under regulated deficit irrigation: A meta-analysis. Agric. Water Manag. 2019, 222, 301-312. [CrossRef]

102. Sadras, V.O. Does partial root-zone drying improve irrigation water productivity in the field? A meta-analysis. Irrig. Sci. 2008, 27, 183-190. [CrossRef]

103. Yu, L.; Zhao, X.; Gao, X.; Siddique, K.H.M. Improving/maintaining water-use efficiency and yield of wheat by deficit irrigation: A global meta-analysis. Agric. Water Manag. 2020, 228, 105906. [CrossRef]

104. Zheng, H.; Ying, H.; Yin, Y.; Wang, Y.; He, G.; Bian, Q.; Cui, Z.; Yang, Q. Irrigation leads to greater maize yield at higher water productivity and lower environmental costs: A global meta-analysis. Agric. Ecosyst. Environ. 2019, 273, 62-69. [CrossRef]

105. Amenumey, S.; Sands, G.; Wilson, B.; Mulla, D.; Nieber, J.; Swenson, J. Meta-analysis as a statistical tool for evaluating the hydrologic effects of water table management. In Proceedings of the American Society of Agricultural and Biological Engineers Annual International Meeting 2009, ASABE 2009, Reno, Nevada, 21-24 June 2009; pp. 2787-2804.

106. Christianson, L.; Knoot, T.; Larsen, D.; Tyndall, J.; Helmers, M. Adoption potential of nitrate mitigation practices: An ecosystem services approach. Int. J. Agric. Sustain. 2013, 12, 407-424. [CrossRef]

107. Skaggs, R.W.; Youssef, M.A.; Gilliam, J.W.; Evans, R.O. Effect of controlled drainage on water and nitrogen balances in drained lands. Trans. ASABE 2010, 53, 1843-1850. [CrossRef]

108. Wang, Z.; Shao, G.; Lu, J.; Zhang, K.; Gao, Y.; Ding, J. Effects of controlled drainage on crop yield, drainage water quantity and quality: A meta-analysis. Agric. Water Manag. 2020, 239, 106253. [CrossRef]

109. Abdalla, M.; Hastings, A.; Truu, J.; Espenberg, M.; Mander, U.; Smith, P. Emissions of methane from northern peatlands: A review of management impacts and implications for future management options. Ecol. Evol. 2016, 6, 7080-7102. [CrossRef]

110. Yagi, K.; Sriphirom, P.; Cha-un, N.; Fusuwankaya, K.; Chidthaisong, A.; Damen, B.; Towprayoon, S. Potential and promisingness of technical options for mitigating greenhouse gas emissions from rice cultivation in Southeast Asian countries. Soil Sci. Plant Nutr. 2019, 66, 37-49. [CrossRef] 
111. Pittelkow, C.M.; Liang, X.; Linquist, B.A.; van Groenigen, K.J.; Lee, J.; Lundy, M.E.; van Gestel, N.; Six, J.; Venterea, R.T.; van Kessel, C. Productivity limits and potentials of the principles of conservation agriculture. Nature 2015, 517, 365-368. [CrossRef]

112. Kiran Kumara, T.M.; Kandpal, A.; Pal, S. A meta-analysis of economic and environmental benefits of conservation agriculture in South Asia. J. Environ. Manag. 2020, 269, 110773. [CrossRef]

113. Manley, J.; Van Kooten, G.C.; Moeltner, K.; Johnson, D.W. Creating carbon offsets in agriculture through no-till cultivation: A meta-analysis of costs and carbon benefits. Clim. Change 2005, 68, 41-65. [CrossRef]

114. Briones, M.J.I.; Schmidt, O. Conventional tillage decreases the abundance and biomass of earthworms and alters their community structure in a global meta-analysis. Glob. Change Biol. 2017, 23, 4396-4419. [CrossRef]

115. Li, Y.; Zhang, Q.; Cai, Y.; Yang, Q.; Chang, S.X. Minimum tillage and residue retention increase soil microbial population size and diversity: Implications for conservation tillage. Sci. Total Environ. 2020, 716, 137164. [CrossRef] [PubMed]

116. Moos, J.H.; Schrader, S.; Paulsen, H.M. Reduced tillage enhances earthworm abundance and biomass in organic farming: A meta-analysis. Landbauforschung 2017, 67, 123-128. [CrossRef]

117. Li, Y.; Li, Z.; Cui, S.; Jagadamma, S.; Zhang, Q. Residue retention and minimum tillage improve physical environment of the soil in croplands: A global meta-analysis. Soil Tillage Res. 2019, 194, 104292. [CrossRef]

118. Mondal, S.; Chakraborty, D.; Bandyopadhyay, K.; Aggarwal, P.; Rana, D.S. A global analysis of the impact of zero-tillage on soil physical condition, organic carbon content, and plant root response. Land Degrad. Dev. 2020, 31, 557-567. [CrossRef]

119. Peixoto, D.S.; Silva, L.; Melo, L.B.B.; Azevedo, R.P.; Araujo, B.C.L.; Carvalho, T.S.; Moreira, S.G.; Curi, N.; Silva, B.M. Occasional tillage in no-tillage systems: A global meta-analysis. Sci. Total Environ. 2020, 745, 140887. [CrossRef] [PubMed]

120. Jia, L.; Zhao, W.; Fu, B.; Daryanto, S.; Wang, S.; Liu, Y.; Zhai, R. Effects of minimum soil disturbance practices on controlling water erosion in China's slope farmland: A meta-analysis. Land Degrad. Dev. 2019, 30, 706-716. [CrossRef]

121. Sun, Y.; Zeng, Y.; Shi, Q.; Pan, X.; Huang, S. No-tillage controls on runoff: A meta-analysis. Soil Tillage Res. $2015,153,1-6$. [CrossRef]

122. Elias, D.; Wang, L.; Jacinthe, P.A. A meta-analysis of pesticide loss in runoff under conventional tillage and no-till management. Environ. Monit. Assess. 2018, 190, 79. [CrossRef]

123. Nunes, M.R.; Karlen, D.L.; Veum, K.S.; Moorman, T.B.; Cambardella, C.A. Biological soil health indicators respond to tillage intensity: A US meta-analysis. Geoderma 2020, 369, 114335. [CrossRef]

124. Li, Y.; Song, D.; Liang, S.; Dang, P.; Qin, X.; Liao, Y.; Siddique, K.H.M. Effect of no-tillage on soil bacterial and fungal community diversity: A meta-analysis. Soil Tillage Res. 2020, 204, 104721. [CrossRef]

125. Chen, H.; Dai, Z.; Veach, A.M.; Zheng, J.; Xu, J.; Schadt, C.W. Global meta-analyses show that conservation tillage practices promote soil fungal and bacterial biomass. Agric. Ecosyst. Environ. 2020, 293, 106841. [CrossRef]

126. Jia, L.; Zhao, W.; Zhai, R.; An, Y.; Pereira, P. Quantifying the effects of contour tillage in controlling water erosion in China: A meta-analysis. Catena 2020, 195, 104829. [CrossRef]

127. Sun, W.; Canadell, J.G.; Yu, L.; Yu, L.; Zhang, W.; Smith, P.; Fischer, T.; Huang, Y. Climate drives global soil carbon sequestration and crop yield changes under conservation agriculture. Glob. Change Biol. 2020, 26, 3325-3335. [CrossRef] [PubMed]

128. Wang, J.; Pan, Z.; Pan, F.; He, D.; Pan, Y.; Han, G.; Huang, N.; Zhang, Z.; Yin, W.; Zhang, J.; et al. The regional water-conserving and yield-increasing characteristics and suitability of soil tillage practices in Northern China. Agric. Water Manag. 2020, $228,105883$. [CrossRef]

129. Li, Y.; Li, Z.; Cui, S.; Zhang, Q. Trade-off between soil pH, bulk density and other soil physical properties under global no-tillage agriculture. Geoderma 2020, 361, 114099. [CrossRef]

130. Wang, Y.; Guo, T.; Qi, L.; Zeng, H.; Liang, Y.; Wei, S.; Gao, F.; Wang, L.; Zhang, R.; Jia, Z. Meta-analysis of ridge-furrow cultivation effects on maize production and water use efficiency. Agric. Water Manag. 2020, 234, 106144. [CrossRef]

131. Abdalla, K.; Chivenge, P.; Ciais, P.; Chaplot, V. No-tillage lessens soil $\mathrm{CO}_{2}$ emissions the most under arid and sandy soil conditions: Results from a meta-analysis. Biogeosciences 2016, 13, 3619-3633. [CrossRef]

132. Aguilera, E.; Lassaletta, L.; Gattinger, A.; Gimeno, B.S. Managing soil carbon for climate change mitigation and adaptation in Mediterranean cropping systems: A meta-analysis. Agric. Ecosyst. Environ. 2013, 168, 25-36. [CrossRef]

133. Angers, D.A.; Eriksen-Hamel, N.S. Full-Inversion Tillage and Organic Carbon Distribution in Soil Profiles: A Meta-Analysis. Soil Sci. Soc. Am. J. 2008, 72, 1370-1374. [CrossRef]

134. Cooper, J.; Baranski, M.; Stewart, G.; Nobel-de Lange, M.; Bàrberi, P.; Fließbach, A.; Peigné, J.; Berner, A.; Brock, C.; Casagrande, M.; et al. Shallow non-inversion tillage in organic farming maintains crop yields and increases soil C stocks: A meta-analysis. Agron. Sustain. Dev. 2016, 36, 22. [CrossRef]

135. de Graaff, M.-A.; Hornslein, N.; Throop, H.L.; Kardol, P.; van Diepen, L.T.A. Effects of agricultural intensification on soil biodiversity and implications for ecosystem functioning: A meta-analysis. Adv. Agron. 2019, 155, 1-44. [CrossRef]

136. González-Sánchez, E.J.; Ordóñez-Fernández, R.; Carbonell-Bojollo, R.; Veroz-González, O.; Gil-Ribes, J.A. Meta-analysis on atmospheric carbon capture in Spain through the use of conservation agriculture. Soil Tillage Res. 2012, 122, 52-60. [CrossRef]

137. Huang, Y.; Ren, W.; Wang, L.; Hui, D.; Grove, J.H.; Yang, X.; Tao, B.; Goff, B. Greenhouse gas emissions and crop yield in no-tillage systems: A meta-analysis. Agric. Ecosyst. Environ. 2018, 268, 144-153. [CrossRef]

138. Lee, H.; Lautenbach, S.; Nieto, A.P.G.; Bondeau, A.; Cramer, W.; Geijzendorffer, I.R. The impact of conservation farming practices on Mediterranean agro-ecosystem services provisioning_A meta-analysis. Reg. Environ. Change 2019, 19, 2187-2202. [CrossRef] 
139. Li, M.; Wang, J.; Guo, D.; Yang, R.; Fu, H. Effect of land management practices on the concentration of dissolved organic matter in soil: A meta-analysis. Geoderma 2019, 344, 74-81. [CrossRef]

140. Li, S.; Zheng, X.; Liu, C.; Yao, Z.; Zhang, W.; Han, S. Influences of observation method, season, soil depth, land use and management practice on soil dissolvable organic carbon concentrations: A meta-analysis. Sci. Total Environ. 2018, 631-632, 105-114. [CrossRef] [PubMed]

141. Luo, Z.; Wang, E.; Sun, O.J. Can no-tillage stimulate carbon sequestration in agricultural soils? A meta-analysis of paired experiments. Agric. Ecosyst. Environ. 2010, 139, 224-231. [CrossRef]

142. Mahal, N.K.; Castellano, M.J.; Miguez, F.E. Conservation Agriculture Practices Increase Potentially Mineralizable Nitrogen: A Meta-Analysis. Soil Sci. Soc. Am. J. 2018, 82, 1270-1278. [CrossRef]

143. Mei, K.; Wang, Z.; Huang, H.; Zhang, C.; Shang, X.; Dahlgren, R.A.; Zhang, M.; Xia, F. Stimulation of $\mathrm{N}_{2} \mathrm{O}$ emission by conservation tillage management in agricultural lands: A meta-analysis. Soil Tillage Res. 2018, 182, 86-93. [CrossRef]

144. Ugarte, C.M.; Kwon, H.; Andrews, S.S.; Wander, M.M. A meta-analysis of soil organic matter response to soil management practices: An approach to evaluate conservation indicators. J. Soil Water Conserv. 2014, 69, 422-430. [CrossRef]

145. Velthof, G.; Commelin, M.; Ros, M.; Oenema, O.; Klages, S.; Tendler, L.; Rowbottom, J.; Wright, I.; Doody, D.; Farrow, L.; et al. Identification of Most Promising Measures and Practices; Report D4.3, Fairway Report Series; Wageningen University and Research: Wageningen, The Netherlands, 2020.

146. Du, Z.; Angers, D.A.; Ren, T.; Zhang, Q.; Li, G. The effect of no-till on organic C storage in Chinese soils should not be overemphasized: A meta-analysis. Agric. Ecosyst. Environ. 2017, 236, 1-11. [CrossRef]

147. Feng, J.; Chen, C.; Zhang, Y.; Song, Z.; Deng, A.; Zheng, C.; Zhang, W. Impacts of cropping practices on yield-scaled greenhouse gas emissions from rice fields in China: A meta-analysis. Agric. Ecosyst. Environ. 2013, 164, 220-228. [CrossRef]

148. Wang, Y.; Zhang, Y.; Zhou, S.; Wang, Z. Meta-analysis of no-tillage effect on wheat and maize water use efficiency in China. Sci. Total Environ. 2018, 635, 1372-1382. [CrossRef]

149. Wei, H.; Wang, S.; Yang, W.; Sun, H.; Yin, L.; Deng, X. Meta analysis on impact of no-tillage and subsoiling tillage on spring maize and winter wheat yield and water use efficiency on the loess plateau. Sci. Agric. Sin. 2017, 50, 461-473. [CrossRef]

150. Xu, C.; Han, X.; Bol, R.; Smith, P.; Wu, W.; Meng, F. Impacts of natural factors and farming practices on greenhouse gas emissions in the North China Plain: A meta-analysis. Ecol. Evol. 2017, 7, 6702-6715. [CrossRef]

151. Yin, M.; Li, Y.; Chen, P.; Xu, L.; Shen, S.; Wang, X. Effect of no-tillage on maize yield in northern region of China-a meta-analysis. Sci. Agric. Sin. 2018, 51, 843-854. [CrossRef]

152. Zhao, X.; Liu, S.-L.; Pu, C.; Zhang, X.-Q.; Xue, J.-F.; Ren, Y.-X.; Zhao, X.-L.; Chen, F.; Lal, R.; Zhang, H.-L. Crop yields under no-till farming in China: A meta-analysis. Eur. J. Agron. 2017, 84, 67-75. [CrossRef]

153. Zhao, X.; Liu, S.L.; Pu, C.; Zhang, X.Q.; Xue, J.F.; Zhang, R.; Wang, Y.Q.; Lal, R.; Zhang, H.L.; Chen, F. Methane and nitrous oxide emissions under no-till farming in China: A meta-analysis. Glob. Change Biol. 2016, 22, 1372-1384. [CrossRef]

154. Karp, D.S.; Chaplin-Kramer, R.; Meehan, T.D.; Martin, E.A.; DeClerck, F.; Grab, H.; Gratton, C.; Hunt, L.; Larsen, A.E.; MartinezSalinas, A.; et al. Crop pests and predators exhibit inconsistent responses to surrounding landscape composition. Proc. Natl. Acad. Sci. USA 2018, 115, E7863-E7870. [CrossRef]

155. Muneret, L.; Mitchell, M.; Seufert, V.; Aviron, S.; Djoudi, E.A.; Pétillon, J.; Plantegenest, M.; Thiéry, D.; Rusch, A. Evidence that organic farming promotes pest control. Nat. Sustain. 2018, 1, 361-368. [CrossRef]

156. Lesur-Dumoulin, C.; Malézieux, E.; Ben-Ari, T.; Langlais, C.; Makowski, D. Lower average yields but similar yield variability in organic versus conventional horticulture. A meta-analysis. Agron. Sustain. Dev. 2017, 37, 45. [CrossRef]

157. Garratt, M.P.D.; Wright, D.J.; Leather, S.R. The effects of farming system and fertilisers on pests and natural enemies: A synthesis of current research. Agric. Ecosyst. Environ. 2011, 141, 261-270. [CrossRef]

158. Butler, J.; Garratt, M.P.D.; Leather, S.R. Fertilisers and insect herbivores: A meta-analysis. Ann. Appl. Biol. 2012, 161, 223-233. [CrossRef]

159. Veresoglou, S.D.; Barto, E.K.; Menexes, G.; Rillig, M.C. Fertilization affects severity of disease caused by fungal plant pathogens. Plant Pathol. 2013, 62, 961-969. [CrossRef]

160. Morris, E.K.; Fletcher, R.; Veresoglou, S.D. Effective methods of biofumigation: A meta-analysis. Plant Soil 2019, 446, 379-392. [CrossRef]

161. Shrestha, U.; Auge, R.M.; Butler, D.M. A Meta-Analysis of the Impact of Anaerobic Soil Disinfestation on Pest Suppression and Yield of Horticultural Crops. Front. Plant Sci. 2016, 7, 1254. [CrossRef]

162. Bonanomi, G.; Antignani, V.; Capodilupo, M.; Scala, F. Identifying the characteristics of organic soil amendments that suppress soilborne plant diseases. Soil Biol. Biochem. 2010, 42, 136-144. [CrossRef]

163. Verret, V.; Gardarin, A.; Pelzer, E.; Médiène, S.; Makowski, D.; Valantin-Morison, M. Can legume companion plants control weeds without decreasing crop yield? A meta-analysis. Field Crop. Res. 2017, 204, 158-168. [CrossRef]

164. Daryanto, S.; Fu, B.; Wang, L.; Jacinthe, P.-A.; Zhao, W. Quantitative synthesis on the ecosystem services of cover crops. Earth-Sci. Rev. 2018, 185, 357-373. [CrossRef]

165. Anderson, R.L. Integrating a complex rotation with no-till improves weed management in organic farming. A review. Agron. Sustain. Dev. 2015, 35, 967-974. [CrossRef]

166. Nichols, V.; Verhulst, N.; Cox, R.; Govaerts, B. Weed dynamics and conservation agriculture principles: A review. Field Crop. Res. 2015, 183, 56-68. [CrossRef] 
167. Peigné, J.; Ball, B.; Roger-Estrade, J.; David, C. Is conservation tillage suitable for organic farming? A review. Soil Use Manag. 2007, 23, 129-144. [CrossRef]

168. Zhang, L.; Rana, I.; Shaffer, R.M.; Taioli, E.; Sheppard, L. Exposure to glyphosate-based herbicides and risk for non-Hodgkin lymphoma: A meta-analysis and supporting evidence. Mutat. Res. Rev. Mutat. Res. 2019, 781, 186-206. [CrossRef] [PubMed]

169. Nguyen, D.B.; Rose, M.T.; Rose, T.J.; Morris, S.G.; Van Zwieten, L. Impact of glyphosate on soil microbial biomass and respiration: A meta-analysis. Soil Biol. Biochem. 2016, 92, 50-57. [CrossRef]

170. Govaerts, B.; Verhulst, N.; Castellanos-Navarrete, A.; Sayre, K.D.; Dixon, J.; Dendooven, L. Conservation Agriculture and Soil Carbon Sequestration: Between Myth and Farmer Reality. Crit. Rev. Plant Sci. 2009, 28, 97-122. [CrossRef]

171. Turmel, M.-S.; Speratti, A.; Baudron, F.; Verhulst, N.; Govaerts, B. Crop residue management and soil health: A systems analysis. Agric. Syst. 2015, 134, 6-16. [CrossRef]

172. Gu, X.; Cai, H.; Fang, H.; Li, Y.; Chen, P.; Li, Y. Effects of degradable film mulching on crop yield and water use efficiency in China: A meta-analysis. Soil Tillage Res. 2020, 202, 104676. [CrossRef]

173. Tofanelli, M.B.D.; Wortman, S.E. Benchmarking the agronomic performance of biodegradable mulches against polyethylene mulch film: A meta-analysis. Agronomy 2020, 10, 1618. [CrossRef]

174. Kallenbach, C.; Grandy, A.S. Controls over soil microbial biomass responses to carbon amendments in agricultural systems: A meta-analysis. Agric. Ecosyst. Environ. 2011, 144, 241-252. [CrossRef]

175. Charles, A.; Rochette, P.; Whalen, J.K.; Angers, D.A.; Chantigny, M.H.; Bertrand, N. Global nitrous oxide emission factors from agricultural soils after addition of organic amendments: A meta-analysis. Agric. Ecosyst. Environ. 2017, 236, 88-98. [CrossRef]

176. Shan, J.; Yan, X. Effects of crop residue returning on nitrous oxide emissions in agricultural soils. Atmos. Environ. 2013, 71, 170-175. [CrossRef]

177. Chen, H.; Li, X.; Hu, F.; Shi, W. Soil nitrous oxide emissions following crop residue addition: A meta-analysis. Glob. Change Biol. 2013, 19, 2956-2964. [CrossRef] [PubMed]

178. Essich, L.; Nkebiwe, P.M.; Schneider, M.; Ruser, R. Is Crop Residue Removal to Reduce $\mathrm{N}_{2} \mathrm{O}$ Emissions Driven by Quality or Quantity? A Field Study and Meta-Analysis. Agriculture 2020, 10, 546. [CrossRef]

179. Qin, W.; Hu, C.; Oenema, O. Soil mulching significantly enhances yields and water and nitrogen use efficiencies of maize and wheat: A meta-analysis. Sci. Rep. 2015, 5, 16210. [CrossRef]

180. Mo, F.; Yu, K.L.; Crowther, T.W.; Wang, J.Y.; Zhao, H.; Xiong, Y.C.; Liao, Y.C. How plastic mulching affects net primary productivity, soil $\mathrm{C}$ fluxes and organic carbon balance in dry agroecosystems in China. J. Clean. Prod. 2020, 263, 121470. [CrossRef]

181. Wang, L.; Coulter, J.A.; Li, L.; Luo, Z.; Chen, Y.; Deng, X.; Xie, J. Plastic mulching reduces nitrogen footprint of food crops in China: A meta-analysis. Sci. Total Environ. 2020, 748, 141479. [CrossRef]

182. Wang, N.; Ding, D.; Malone, R.W.; Chen, H.; Wei, Y.; Zhang, T.; Luo, X.; Li, C.; Chu, X.; Feng, H. When does plastic-film mulching yield more for dryland maize in the Loess Plateau of China? A meta-analysis. Agric. Water Manag. 2020, 240, 106290. [CrossRef]

183. Lu, X. A meta-analysis of the effects of crop residue return on crop yields and water use efficiency. PLoS ONE 2020, 15, e0231740. [CrossRef]

184. Zhao, X.; Liu, B.Y.; Liu, S.L.; Qi, J.Y.; Wang, X.; Pu, C.; Li, S.S.; Zhang, X.Z.; Yang, X.G.; Lal, R.; et al. Sustaining crop production in China's cropland by crop residue retention: A meta-analysis. Land Degrad. Dev. 2020, 31, 694-709. [CrossRef]

185. Chen, G.; Liu, S.; Xiang, Y.; Tang, X.; Liu, H.; Yao, B.; Luo, X. Impact of living mulch on soil C:N:P stoichiometry in orchards across China: A meta-analysis examining climatic, edaphic, and biotic dependency. Pedosphere 2020, 30, 181-189. [CrossRef]

186. Xiao, L.; Zhao, R.; Zhang, X. Crop cleaner production improvement potential under conservation agriculture in China: A meta-analysis. J. Clean. Prod. 2020, 269, 122262. [CrossRef]

187. Li, Q.; Li, H.; Zhang, L.; Zhang, S.; Chen, Y. Mulching improves yield and water-use efficiency of potato cropping in China: A meta-analysis. Field Crop. Res. 2018, 221, 50-60. [CrossRef]

188. Gao, H.; Yan, C.; Liu, Q.; Li, Z.; Yang, X.; Qi, R. Exploring optimal soil mulching to enhance yield and water use efficiency in maize cropping in China: A meta-analysis. Agric. Water Manag. 2019, 225, 105741. [CrossRef]

189. Mazoyer, M.; Roudart, L. A History of World Agriculture-From the Neolithic Age to the Current Crisis; Earthscan: London, UK, 2006.

190. Keller, T.; Sandin, M.; Colombi, T.; Horn, R.; Or, D. Historical increase in agricultural machinery weights enhanced soil stress levels and adversely affected soil functioning. Soil Tillage Res. 2019, 194, 104293. [CrossRef]

191. Ampoorter, E.; de Schrijver, A.; van Nevel, L.; Hermy, M.; Verheyen, K. Impact of mechanized harvesting on compaction of sandy and clayey forest soils: Results of a meta-analysis. Ann. For. Sci. 2012, 69, 533-542. [CrossRef]

192. Dahlin, A.S.; Rusinamhodzi, L. Yield and labor relations of sustainable intensification options for smallholder farmers in sub-Saharan Africa. A meta-analysis. Agron. Sustain. Dev. 2019, 39, 32. [CrossRef]

193. Arts, B.; Buizer, M.; Horlings, L.; Ingram, V.; van Oosten, C.; Opdam, P. Landscape Approaches: A State-of-the-Art Review. Annu. Rev. Environ. Resour. 2017, 42, 439-463. [CrossRef]

194. FAO. Landscapes for Life: Integrated Management of Landscapes and Seascapes for Sustainable Food and Agriculture; FAO: Rome, Italy, 2017.

195. Freeman, O.E.; Duguma, L.A.; Minang, P.A. Operationalizing the integrated landscape approach in practice. Ecol. Soc. 2015, 20, 24. [CrossRef]

196. Kort, J. Benefits of windbreaks to field and forage crops. Agric. Ecosyst. Environ. 1988, 22-23, 165-190. [CrossRef] 
197. Albrecht, M.; Kleijn, D.; Williams, N.M.; Tschumi, M.; Blaauw, B.R.; Bommarco, R.; Campbell, A.J.; Dainese, M.; Drummond, F.A.; Entling, M.H. The effectiveness of flower strips and hedgerows on pest control, pollination services and crop yield: A quantitative synthesis. Ecol. Lett. 2020, 23, 1488-1498. [CrossRef]

198. Van Vooren, L.; Reubens, B.; Broekx, S.; De Frenne, P.; Nelissen, V.; Pardon, P.; Verheyen, K. Ecosystem service delivery of agri-environment measures: A synthesis for hedgerows and grass strips on arable land. Agric. Ecosyst. Environ. 2017, $244,32-51$. [CrossRef]

199. Zamorano, J.; Bartomeus, I.; Grez, A.A.; Garibaldi, L.A. Field margin floral enhancements increase pollinator diversity at the field edge but show no consistent spillover into the crop field: A meta-analysis. Insect Conserv. Divers. 2020, 13, 519-531. [CrossRef]

200. Zheng, Y.; Wang, H.; Qin, Q.; Wang, Y. Effect of plant hedgerows on agricultural non-point source pollution: A meta-analysis. Environ. Sci. Pollut. Res. 2020, 27, 24831-24847. [CrossRef]

201. Marja, R.; Kleijn, D.; Tscharntke, T.; Klein, A.M.; Frank, T.; Batáry, P. Effectiveness of agri-environmental management on pollinators is moderated more by ecological contrast than by landscape structure or land-use intensity. Ecol. Lett. 2019, 22, 1493-1500. [CrossRef] [PubMed]

202. FAO. The State of Food and Agriculture 2020: Overcoming Water Challenges in Agriculture; FAO: Rome, Italy, 2020.

203. IPBES. Global Assessment Report on Biodiversity and Ecosystem Services of the Intergovernmental Science-Policy Platform on Biodiversity and Ecosystem Services; IPBES Secretariat: Bonn, Germany, 2019.

204. UN. Transforming Our World: The 2030 Afenda for Sustainable Development; United Nations: New York, NY, USA, 2015.

205. Mueller, N.D.; Gerber, J.S.; Johnston, M.; Ray, D.K.; Ramankutty, N.; Foley, J.A. Closing yield gaps through nutrient and water management. Nature 2012, 490, 254-257. [CrossRef] [PubMed]

206. Mekonnen, M.M.; Hoekstra, A.Y. Four billion people facing severe water scarcity. Sci. Adv. 2016, 2, e1500323. [CrossRef]

207. Cordell, D.; Drangert, J.-O.; White, S. The story of phosphorus: Global food security and food for thought. Glob. Environ. Change 2009, 19, 292-305. [CrossRef]

208. van Kauwenbergh, S.J. World Phosphate Rock Reserves and Resources; International Fertilizer Development Center (IFDC): Muscle Shoals, AL, USA, 2010.

209. Sutton, M.A.; Bleeker, A.; Howard, C.M.; Bekunda, M.; Grizzetti, B.; de Vries, W.; van Grinsven, H.J.M.; Abrol, Y.P.; Adhya, T.K.; Billen, G.; et al. Our Nutrient World: The Challenge to Produce More Food and Energy with Less Pollution; Centre for Ecology and Hydrology (CEH): Edinburgh, UK, 2013.

210. Shannon, D.K.; Clay, D.E.; Kitchen, N.R. Precision Agriculture Basics; American Society of Agronomy: Madison, WI, USA, 2018.

211. Stafford, J.V. Precisoin Agriculture'19; Wageningen Academic Publisher: Wageningen, The Netherlands, 2019.

212. Zhang, Q. Precision Agriculture Technology for Crop Farming; CRC Press: Boca Raton, FL, USA, 2016.

213. De Wit, C.T. Resource Use Efficiency in Agriculture. Agric. Syst. 1992, 40, 125-151. [CrossRef]

214. Willett, W.; Rockström, J.; Loken, B.; Springmann, M.; Lang, T.; Vermeulen, S.; Garnett, T.; Tilman, D.; DeClerck, F.; Wood, A.; et al. Food in the Anthropocene: The EAT-Lancet Commission on healthy diets from sustainable food systems. Lancet 2019, 393, 447-492. [CrossRef] 